Article

\title{
Evidence of Hydrocarbon-Rich Fluid Interaction with Clays: Clay Mineralogy and Boron Isotope Data from Gulf of Cádiz Mud Volcano Sediments
}

\author{
Rubén Martos-Villa ${ }^{1}$, M. Pilar Mata ${ }^{2, *}{ }^{(0)}$, Lynda B. Williams ${ }^{3}$, Fernando Nieto ${ }^{4,5}{ }^{\circ}$, \\ Xabier Arroyo Rey ${ }^{6}$ and C. Ignacio Sainz-Díaz ${ }^{4}$ \\ 1 Facultad de Ciencias del Mar y Ambientales, Universidad de Cádiz, Av. República Saharaui s/n, \\ 11510 Puerto Real, Spain; ruben.martos@uca.es \\ 2 Instituto Geológico y Minero de España, Rios Rosas, 23, 28003 Madrid, Spain \\ 3 School of Earth \& Space Exploration, Arizona State University, Tempe, AZ 85287-1404, USA; \\ Lynda.Williams@asu.edu \\ 4 Instituto Andaluz de Ciencias de la Tierra, CSIC-Universidad de Granada, Av. De las Palmeras, 4, \\ 18100 Granada, Spain; nieto@ugr.es (F.N.); ci.sainz@csic.es (C.I.S.-D.) \\ 5 Universidad de Granada-CSIC, Av. Fuentenueva s/n, 18002 Granada, Spain \\ 6 Centro de Asistencia a la Investigación de Técnicas Geológicas, Universidad Complutense de Madrid, \\ Jose Antonio Novais 2, 28040 Madrid, Spain; xarroyo@geo.ucm.es \\ * Correspondence: p.mata@igme.es; Tel.: +34-917287256
}

Received: 25 May 2020; Accepted: 17 July 2020; Published: 23 July 2020

\begin{abstract}
Clay dehydration at great depth generates fluids and overpressures in organic-rich sediments that can release isotopically light boron from mature organic matter, producing ${ }^{10} \mathrm{~B}$-rich fluids. The B can be incorporated into the tetrahedral sites of authigenic illite during the illitization of smectite. Therefore, the crystal-chemical and geochemical characterization of illite, smectite or interlayered illite-smectite clay minerals can be an indicator of depth (temperature) and reactions with the basin fluids. The aim of this study was to determine the detailed clay mineralogy, B-content and isotopic composition in illite-smectite rich samples of mud volcanoes from the Gulf of Cádiz, in order to evaluate interactions of hydrocarbon-rich fluids with clays. Molecular modeling of the illite structure was performed, using electron density functional theory (DFT) methods to examine the phenomenon of $\mathrm{B}$ incorporation into illite at the atomic level. We found that it is energetically preferable for $B$ to reside in the tetrahedral sites replacing $\mathrm{Si}$ atoms than in the interlayer of expandable clays. The B abundances in this study are high and consistent with previous results of B data on interstitial fluids, suggesting that hydrocarbon-related fluids approaching temperatures of methane generation $\left(150^{\circ} \mathrm{C}\right)$ are the likely source of B-rich illite in the studied samples.
\end{abstract}

Keywords: mud volcano; B isotopes; illite-smectite; molecular modelling fluids; Gulf of Cádiz; hydrocarbons

\section{Introduction}

Mud volcanoes (MVs) are generated by extrusion activity involving the transport of clay-rich sediments, liquids and gases (mainly methane) from deeper regions to the surface [1-8]. In recent years, both the source of material and fluids have been the focus of research as they give us important information about the presence of hydrocarbon resources at depth or global methane fluxes to the atmosphere [9-12]. Extensive work has been done in the study of fluid sources and pathways in sedimentary basins, where a close relation exists between fluids and the nature of clays, as a result of clay dehydration at depth resulting in smectite illitization processes [13]. The illitization process 
generates fluids and overpressures at temperature ranges of $\sim 80$ to $\sim 150{ }^{\circ} \mathrm{C}[14-16]$ and smectite is transformed to randomly interstratified (R0) illite-smectite minerals (I-S) and to more illitic ordered (R1-R3) I-S [14-19].

Boron is abundant in marine sediments [20] and sedimentary clay minerals illite/smectite (I-S) [21,22], which contain orders of magnitude more boron than other common diagenetic minerals (e.g., quartz, carbonates and feldspars). Boron is a highly mobile element, preferring aqueous phases to that of most minerals [23]. Thus, by understanding how the aqueous B is incorporated into clay minerals, important insights may be gained to the fluid and chemical dynamics of a sedimentary basin. To use this geochemical tool, one must be able to interpret the boron isotopic composition of paleofluids that were present in a basin at the time of clay mineral diagenesis. Boron is incorporated into the clay mineral structure in tetrahedral sites and can also be adsorbed to clay surfaces, including those in the clay interlayers [24,25]. $\mathrm{B}$ adsorption on clays causes a preferential ${ }^{10} \mathrm{~B}$ uptake in tetrahedral sites of the clay related to bond strength. There is a coordination change of $\mathrm{B}$ from trigonal in water (at $\mathrm{pH}<7$ ) to tetrahedral on the clay surfaces [26,27]. This fractionation of B isotopes between trigonal and tetrahedral coordination during fluid-rock interactions is temperature dependent and insensitive to mineral composition [24,28].

Several recent studies have highlighted the potential utility of B-isotope ratios as a tracer for fluid-rock interactions $[25,26,29,30]$. The adsorption of B on clay surfaces has been extensively studied [27,31,32], because it can be easily exchanged [26]. However, fixed-B is more useful for interpreting paleofluid B composition because the B-isotopic composition is fixed when B substitutes for $\mathrm{Si}$ as Si-O bonds are broken.

Thermal maturation of organic matter during the burial process produces oil, wet gas and dry gas (mainly methane). Numerous studies of light stable isotopes in clays (e.g., [32-36]) have shown that trace elements (N, B and Li) commonly found in I-S are associated with hydrocarbon-related fluids generated during the maturation of organic source rocks. In these studies, it was shown that the light isotope of each of these "heteroatoms" released from organic matter dominates the fluids, thus these trace elements are ideal tracers of organic inputs to pore fluids. Thus, organic matter can release considerable amounts of $\mathrm{B}$, producing ${ }^{10} \mathrm{~B}$-rich fluids [24]. Late-stage or deep diagenesis of clay minerals [37] coincides with the time/temperatures associated with organic maturation processes that lead to the expulsion and accumulation of hydrocarbons. Thus, ${ }^{10} \mathrm{~B}$-rich fluids are a source of B that can be incorporated into the tetrahedral layers of illite during the process of illitization of smectite at depth. The authigenic illite preferentially incorporates ${ }^{10} \mathrm{~B}$, thus the remaining fluids are relatively enriched in ${ }^{11} \mathrm{~B}$ [24]. Therefore, the crystal-chemical and geochemical characterization of illite, smectite or interlayered illite-smectite (I-S) clay minerals can be an indicator of temperature and reactions with the basin fluids.

Molecular modeling is a useful tool for determining many aspects of minerals at atomistic scale helping the interpretation of many experimental phenomena related with minerals, especially clay minerals [38-40], including with borate anions [41]. In this work, Density Functional Theory (DFT) methods were used to obtain information about the incorporation of B into the clay mineral structure, for understanding the experimental results.

In the Gulf of Cádiz, extensive work has been done on the study of fluid sources and pathways [42-46], including basin-scale reactive-transport models [47]. These studies conclude that clay mineral dehydration during reaction of smectite to illite, from Mesozoic to Tertiary shale and marl units has been the major influence on fluid compositions in many of the Mud volcanoes [42]. Some samples from deep, hotter regions are associated with B and Li-rich fluid compositions, which have been associated with production of methane from organic rich sediments $[48,49]$. The chemical analysis of clay minerals and the study of the diagenetic evolution of these units is therefore of high interest in order to better characterize the fluid circulation system present in fluid venting areas such as the Gulf of Cádiz.

In this work, a detailed mineralogical characterization of samples coming from several mud volcanoes and the content and isotopic values of B in clay minerals were analyzed to determine the 
diagenetic evolution of clay minerals and the possible depth (temperature), origin and interaction of clay minerals present in the mud breccia with the methane bearing fluids.

\section{Geological Setting}

The Gulf of Cádiz is located at the front of the Gibraltar arc, the westernmost tectonic belt of the Alpine Mediterranean compressional system, which has formed in response to the convergence between the African and Eurasian plates. It has a complex geological history and has undergone several episodes of rifting, compression and strike-slip motion since the Triassic [50]. During Tortonian times (11.2-7.1 Ma), allochthonous units took place in the Gulf of Cádiz formed by the westward migration of the Alborán domain associated with the formation of the Betic-Rifian Arc. This Guadalquivir allochthonous unit [51] consists of a mixture of Triassic, Cretaceous, Paleogene and Neogene sedimentary units overlying the Paleozoic basement [50], and is responsible for diapirism of huge volumes of mud and salt of Triassic units and under-compacted Early-Middle Miocene plastic marls [50,51] (Figure 1).

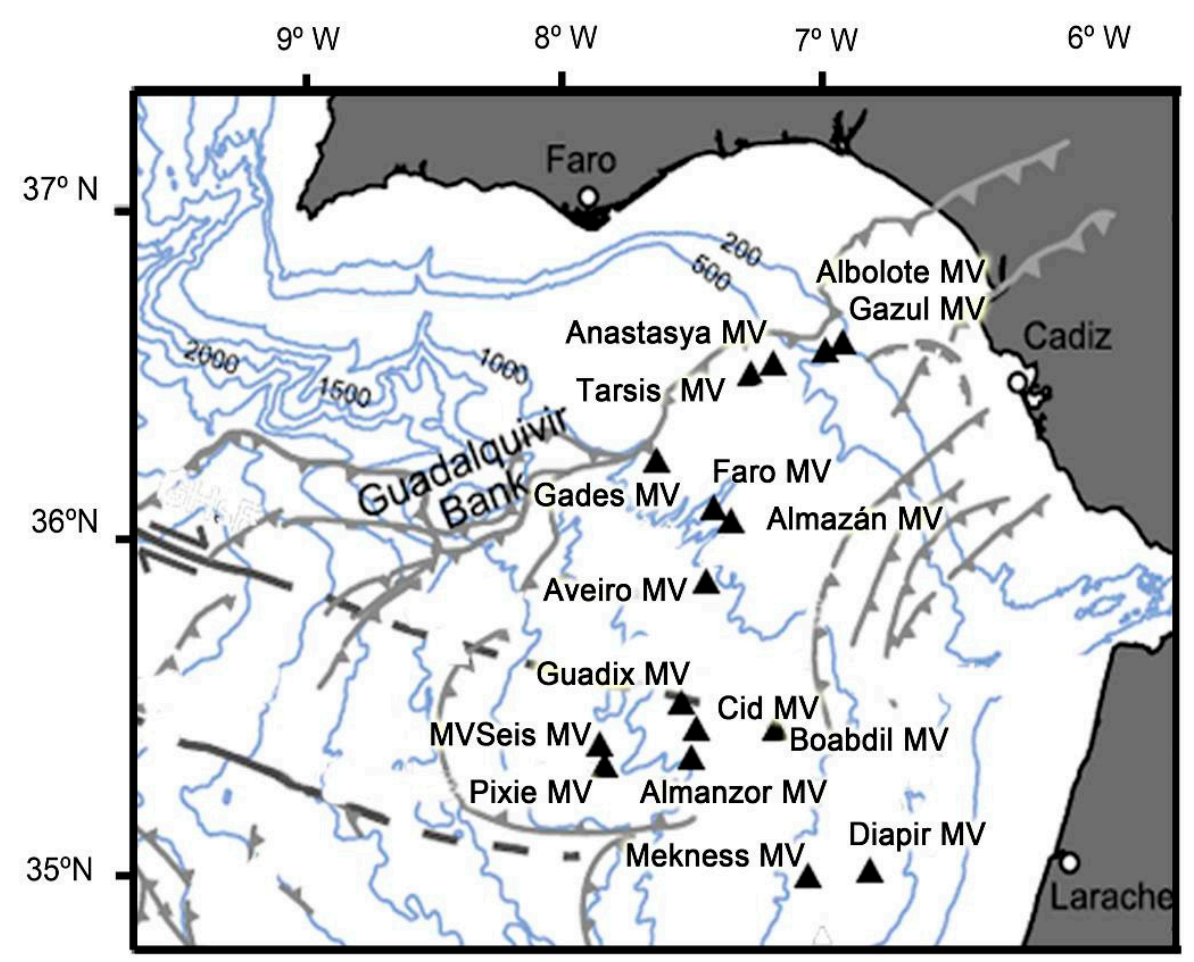

Figure 1. Structural and bathymetrical map of the Gulf of Cádiz. The MVs investigated within this study are represented by triangles. Modified from [44].

Throughout this area, several methane gas-related seafloor structures have been identified, including mud volcanoes, areas of carbonate crusts and chimneys, gas pipes and mud mounds [51-59]. Gravity cores were collected during the ANASTASYA/01, MVSeis/08 and CHICA/11 cruises on board of Cornide de Saavedra and Hespérides. Samples come from short gravity cores (up $2 \mathrm{~m}$ long) taken on the top of 16 mud volcanoes of the Gulf of Cádiz. Table 1 shows the location of the gravity cores of this study. Mud volcanoes are located in several zones in the Gulf of Cádiz (Figure 1) from 353 to $1639 \mathrm{~m}$ depth, more than $100 \mathrm{~km}$ apart from north to south. A detailed description of morphologies and processes can be found in $[55,60]$. Previous studies on the mineralogy of mud breccia [61] show that cores from the mud volcanoes are made of several units (hemipelagic and mud breccia) showing similar bulk mineralogical composition of quartz, clay minerals, scarce calcite and dolomite and pyrite, with slight differences in type of clay minerals between different mud volcanoes. 
Table 1. Geographical position of the MVs sampled in the framework of this study. All M3 samples correspond to a diapiric structure, not a mud volcano.

\begin{tabular}{ccccc}
\hline \multirow{2}{*}{ Mud Volcano } & Samples & Water Depth (m) & \multicolumn{2}{c}{ Location } \\
\cline { 4 - 5 } & & & Lat. & Long. \\
\hline Diapir & M3 10-14 & 600 & $34^{\circ} 59^{\prime} 42.4^{\prime \prime} \mathrm{N}$ & $6^{\circ} 49^{\prime} 50.4^{\prime \prime} \mathrm{W}$ \\
Mekness & M4 18-22 & 694 & $34^{\circ} 59^{\prime} 06.6^{\prime \prime} \mathrm{N}$ & $7^{\circ} 04^{\prime} 21.6^{\prime \prime} \mathrm{W}$ \\
Almanzor & M8 58-62 & 1440 & $35^{\circ} 20^{\prime} 57.6^{\prime \prime} \mathrm{N}$ & $7^{\circ} 30^{\prime} 40.4^{\prime \prime} \mathrm{W}$ \\
Pixie & M12 66-70 & 1639 & $35^{\circ} 20^{\prime} 13.2^{\prime \prime} \mathrm{N}$ & $7^{\circ} 50^{\prime} 38.4^{\prime \prime} \mathrm{W}$ \\
MVSeis & M14 138-142 & 1611 & $35^{\circ} 23^{\prime} 42.6^{\prime \prime} \mathrm{N}$ & $7^{\circ} 51^{\prime} 28.8^{\prime \prime} \mathrm{W}$ \\
Guadix & $\mathrm{M} 2534-38$ & 1435 & $35^{\circ} 30^{\prime} 56.4^{\prime \prime} \mathrm{N}$ & $7^{\circ} 32^{\prime} 45.0^{\prime \prime} \mathrm{W}$ \\
Cid & $\mathrm{M} 2650-54$ & 1330 & $35^{\circ} 26^{\prime} 29.4^{\prime \prime} \mathrm{N}$ & $7^{\circ} 29^{\prime} 04.2^{\prime \prime} \mathrm{W}$ \\
Boabdil & $\mathrm{M} 2718-22$ & 1106 & $35^{\circ} 25^{\prime} 49.2^{\prime \prime} \mathrm{N}$ & $7^{\circ} 10^{\prime} 45.0^{\prime \prime} \mathrm{W}$ \\
Gazul & $\mathrm{M} 29106-110$ & 411 & $36^{\circ} 33^{\prime} 29.4^{\prime \prime} \mathrm{N}$ & $6^{\circ} 56^{\prime} 06.0^{\prime \prime} \mathrm{W}$ \\
Albolote & $\mathrm{C} 332-33$ & 353 & $36^{\circ} 34^{\prime} 27.2^{\prime \prime} \mathrm{N}$ & $6^{\circ} 52^{\prime} 46.6^{\prime \prime} \mathrm{W}$ \\
Tarsis & $\mathrm{C} 436-37$ & 550 & $36^{\circ} 29^{\prime} 17.4^{\prime \prime} \mathrm{N}$ & $7^{\circ} 14^{\prime} 39.9^{\prime \prime} \mathrm{W}$ \\
Anastasya & $\mathrm{C} 738-39, \mathrm{~A} 248-50$ & 457 & $36^{\circ} 31^{\prime} 20.9^{\prime \prime} \mathrm{N}$ & $7^{\circ} 09^{\prime} 04.8^{\prime \prime} \mathrm{W}$ \\
Almazán & $\mathrm{C} 984-85, \mathrm{~A} 870-71$ & 830 & $36^{\circ} 03^{\prime} 08.0^{\prime \prime} \mathrm{N}$ & $7^{\circ} 20^{\prime} 01.6^{\prime \prime} \mathrm{W}$ \\
Aveiro & $\mathrm{C} 1027-28$ & 1060 & $35^{\circ} 52^{\prime} 19.1^{\prime \prime} \mathrm{N}$ & $7^{\circ} 26^{\prime} 15.2^{\prime \prime} \mathrm{W}$ \\
Faro & $\mathrm{A} 1426-30$ & 795 & $36^{\circ} 05^{\prime} 31.8^{\prime \prime} \mathrm{N}$ & $7^{\circ} 23^{\prime} 44.4^{\prime \prime} \mathrm{W}$ \\
Gades & $\mathrm{A} 448-50$ & 915 & $36^{\circ} 14^{\prime} 17.4^{\prime \prime} \mathrm{N}$ & $7^{\circ} 37^{\prime} 01.2^{\prime \prime} \mathrm{W}$ \\
\hline
\end{tabular}

\section{Experimental Methodology}

\subsection{X-ray Diffraction and Deconvolution}

X-ray diffraction (XRD) patterns of oriented samples with a size fraction of $<2 \mu \mathrm{m}$ were obtained using a Bruker D8 Advance diffractometer, located at The University of Cádiz (Cádiz, Spain), with a graphite monochromator, operating at $40 \mathrm{kV}$ and $40 \mathrm{~mA}$ using $\mathrm{Cu}-\mathrm{K} \alpha$ radiation. Each sample was first washed with distilled water until the supernatant was chloride-free, sonicated and then the $<2-\mu \mathrm{m}$ fraction was separated by centrifugation [62]. Each suspension was smeared on glass slides and air dried in atmospheric conditions. The slides were then saturated with ethylene glycol at $80{ }^{\circ} \mathrm{C}$ for $24 \mathrm{~h}$ to ensure maximum saturation. XRD patterns were acquired on the oriented clay mounts in both air dried and ethylene glycol saturated state to determine the percent of illite in I-S [63]. To discriminate between detrital smectite and I-S mixed-layer phases, deconvolution of the patterns obtained from the oriented mount after glycolation were performed using the MacDiff 4.2.6 program (4.2.6, Johann Wolfgang Goethe-Universität, Frankfurt, Germany). The determination of the illite percentage (\% illite) and type of order (Reichweite; R) in I-S was performed according to the position of XRD peaks 001/002 and $002 / 003$ in the regions $8-11^{\circ} 2 \theta$ and $14-19^{\circ} 2 \theta$, respectively $[64,65]$

\subsection{Transmission Electron Microscopy}

Grain morphology within the bulk and $<2-\mu \mathrm{m}$ fractions and quantitative chemical analyses by analytical electron microscopy (AEM) were obtained using a Philips CM20 transmission electron microscope (TEM) at the University of Granada (Granada, Spain). Powdered portions deposited on a holey C-coated Au grid were used to collect AEM spectra in scanning transmission electron microscopy (STEM) mode on areas of $200 \AA \times 1000 \AA$ using a 70- $\AA$ diameter spot size. To check volatilization of light elements, analyses were taken at 15 and $40 \mathrm{~s}$. The structural formulae of smectites, micas and interstratified I-S were calculated on the basis of 22 negative charges, i.e., $\mathrm{O}_{10}(\mathrm{OH})_{2}$, adjusting the occupation of the octahedral sheet to 2 atoms per formula unit.

\subsection{Secondary Ion Mass Spectrometry}

Secondary ion mass spectrometry (SIMS) (Arizona State University SIMS Facility, Tempe, AZ, USA) was used to characterize the content and isotopic composition of B in the clay minerals. Analytical 
protocols for measurement of B contents and $\delta^{11} B$ values have been described elsewhere $[49,66-68]$ and particularly for measurements of clay minerals by [24].

\subsubsection{Sample Preparation}

Boron is strongly adsorbed to the surfaces of clay minerals at room temperature, with a distribution coefficient $>30$ [68]. During burial, B can be found in two sites of clay minerals: exchangeable B in the interlayer and substituted $B$ in the tetrahedral layer. Therefore, special preparations are required to separate exchangeable B from that held in the silicate framework before any isotope analysis of the structurally substituted B. First, the samples were treated with a $1 \mathrm{~N}$ solution of mannitol a B-complexing polyhydric alcohol, which removes exterior surface B contamination [69], but not clay interlayer B. Samples were sonicated in an ultrasonic disaggregator, centrifuged at high speed to concentrate particles (or clusters of minerals), and then washed in triplicate in "B-free" deionized water filtered through Amberlite resin [33]. An aliquot of the mannitol-treated sample was mounted for isotope analysis of the total $B\left(B_{\text {tetrahedral }}+B_{\text {interlayer }}\right)$ by drying a 5-mL suspension onto a one-inch (25-mm) diameter B-free glass slide. Several samples were placed on a single round B-free glass slide, including standards. Then, the measurement of total-B content was determined by SIMS using a calibration curve based on the counts of B (mass 11) relative to $\mathrm{Si}$ (mass 30). The calibration curve was measured on standard reference materials with known B-content [33].

The remaining clay was cation exchanged with $1 \mathrm{~N} \mathrm{NH}_{4} \mathrm{Cl}$ by standard procedures [62] to remove exchangeable B from the interlayer [70]. Samples were rinsed again in mannitol and then mounted for isotope analysis as above. These samples only contain B substituted in tetrahedral sites.

\subsubsection{Boron Content and Isotope Analysis}

A Cameca IMS $6 f$ at Arizona State University (Tempe, AZ, USA) was used with a primary beam of mass-filtered ${ }^{16} \mathrm{O}^{-}$ions accelerated at $12.5 \mathrm{kV}$ onto the sample held at $9 \mathrm{kV}$ for a total impact energy of $\sim 21.5 \mathrm{kV}$. Primary beam currents below $10 \mathrm{nA}$ were used with beam diameters defocused to 40-60 $\mu \mathrm{m}$. Positive secondary ions were accelerated away from the sample, and energy filtering $(-75 \mathrm{~V}$ sample offset) was used for measurements of B-content [66]. No energy filtering was used for isotope ratio measurements.

$\mathrm{B}$ isotope ratios are reported in delta notation as:

$$
\left.\delta^{11} \mathrm{~B}=\left[\left\{\left({ }^{11} \mathrm{~B} /{ }^{10} \mathrm{Bsample}\right) /\left({ }^{11} \mathrm{~B} /{ }^{10} \mathrm{Bstandard}\right)-1\right\}\right\}^{*} 1000\right]-\mathrm{IMF}
$$

where the standard is NBS SRM 951, boric acid, with a ${ }^{11} \mathrm{~B} /{ }^{10} \mathrm{~B}$ ratio of 4.0437 [71]. The instrumental mass fractionation (IMF) is determined by measuring a mineral standard on which the $\delta^{11} \mathrm{~B}$ is known. B-isotope analyses were calibrated by measuring clay mineral standard IMt-1 (Silver Hill Illite) from the Clay Minerals Repository (http://www.clays.org/sourceclays) that had been characterized by bulk thermal ionization mass spectrometry (TIMS) [24], with a $\delta^{11} \mathrm{~B}$ of $-9 \pm 0.6 \%$. The isotope ratio analyses averaged 50-100 cycles of measurements on each spot (depending on the B-content) and analytical errors were compared to predicted errors. Where analytical errors were $>2$ times predicted errors, the analysis was discarded. Multiple spots were analyzed on each sample and results were averaged. The internal standard was measured in between analyses of the unknowns to test for changes in IMF due to instrumental drift.

\subsection{Computational Methodology}

We created models of $\mathrm{Al}(\mathrm{OH})_{3}$ and $\mathrm{B}(\mathrm{OH})_{3}$ molecules enveloped in a hydrogen-bonding network of water molecules which simulates B- and Al-rich fluids that are present in the illitization process (at low $\mathrm{pH}$ ). Two different models of illite structures were also created: one of them with tetrahedral $\mathrm{Al}$ (Al-illite) and the other one with $\mathrm{B}$ incorporated to the tetrahedral layer by replacing the $\mathrm{Al}$ (B-illite). The comparison of energies of these optimized components can show us whether the incorporation 
of $B$ in the tetrahedral sites is energetically favorable. Furthermore, montmorillonite models were created to compare optimization energies between montmorillonite with $\mathrm{B}$ as hydroxide $\left(\mathrm{B}(\mathrm{OH})_{4}{ }^{-}\right)$in the interlayer and montmorillonite with $\mathrm{B}$ in the tetrahedral layer, replacing $\mathrm{Si}$ sites.

The electronic structure of $\mathrm{Al}(\mathrm{OH})_{3}$ and $\mathrm{B}(\mathrm{OH})_{3}$ molecules was studied by quantum chemical calculations with the Hartree-Fock approximation and the second-order Moeller-Plesset method for all electrons. A triple- $\zeta$ basis set with polarization functions was used for all atoms including $\mathrm{H}$ atoms (MP2/6-311G** level) as implemented in the Gaussian03 program package [72]. All geometries were fully optimized using the Berny analytical gradient method. No geometry constraint was applied to the molecules. Normal mode analyses were performed to the same level to confirm the nature of the various stationary points, finding only positive eigenvalues for minima.

$\mathrm{Ab}$ initio total energy calculations of the periodic illite crystal models and $\mathrm{Al}(\mathrm{OH})_{3}$ and $\mathrm{B}(\mathrm{OH})_{3}$ hydrated models were performed using density functional theory (DFT) methods implemented in the SIESTA program (version 3.0, Max Centre of Excellence, Modena, Italy) [73]. The generalized gradient approximation (GGA) was used with the Perdew-Burke-Ernzerhof (PBEsol) parameterization of the exchange-correlation function optimized for solids [74]. Core electrons were replaced by norm-conserving pseudopotentials [75]. Calculations were restricted to the $\Gamma$ point in the irreducible wedge of the Brillouin zone. In all structures, the geometry of each atom was relaxed by means of conjugated gradient optimizations at constant experimental volume. In SIESTA, the basis sets are made of strictly localized numerical atomic orbitals (NAOs) with a localization cut-off radius corresponding to an energy shift of $270 \mathrm{meV}$. The basis sets used here are double-Z polarized (DZP) following the perturbative polarization scheme. This approach was successfully used in previous calculations on phyllosilicates [76] and hydrated systems [77-79]. A uniform mesh with appropriate plane-wave cut-off energy is used to represent the electron density, the local part of the pseudopotential, and the Hartree and exchange-correlation potentials. Total energy calculations were performed with cut-off energy values of 350 Ry. These conditions are consistent with previous studies with phyllosilicates $[39,80]$.

Models

Based on previous works reporting quantum mechanical calculations [81,82], models of hydrated $\mathrm{Al}(\mathrm{OH})_{3}$ and $\mathrm{B}(\mathrm{OH})_{3}$ molecules were created, consisting of $\mathrm{Al}(\mathrm{OH})_{3}$ or $\mathrm{B}(\mathrm{OH})_{3}$ molecules optimized at MP2/6-311G** level, encaged in a cavity of a hydrogen-bonded network formed by 24 water molecules. Those models were also optimized using the DFT methodology implemented in the SIESTA program in the same conditions as the mineral structures.

Illite models were based on previous pyrophyllite models [38]. Pyrophyllite is a dioctahedral phyllosilicate [83] with a structure similar to illite, but without cation substitutions causing the layer charge on basal siloxane surfaces. The trans-vacant crystal form was used in all models [39]. To obtain a reasonable size illite model, a $4 \times 2 \times 1$ supercell was generated. Two types of illite models were created, Al-illite and B-illite. The Al-illite model was generated from the supercell by replacing eight tetrahedrally coordinated $\mathrm{Si}^{4+}$ by $\mathrm{Al}^{3+}$, and four octahedral $\mathrm{Al}^{3+}$ were replaced by $\mathrm{Mg}^{2+}$. Layer charge is balanced by twelve $\mathrm{K}^{+}$cations per supercell in the interlayer, resulting in a simulation cell composition of $\left[\mathrm{K}_{12}\right]\left[\mathrm{Al}_{28} \mathrm{Mg}_{4}\right]\left[\mathrm{Si}_{56} \mathrm{Al}_{8}\right] \mathrm{O}_{160}(\mathrm{OH})_{32}$. The B-illite model was created similar to Al-illite model, but replacing one of tetrahedral $\mathrm{Al}^{3+}$ by $\mathrm{B}^{3+}$, resulting in a simulation cell composition of $\left[\mathrm{K}_{12}\right]\left[\mathrm{Al}_{28} \mathrm{Mg}_{4}\right]\left[\mathrm{Si}_{56} \mathrm{~A}_{7} \mathrm{~B}_{1}\right] \mathrm{O}_{160}(\mathrm{OH})_{32}$.

In both cases, maximum dispersion of the substituted cations in the tetrahedral and octahedral sheets was made according to previous studies [40,84]. Initial lattice parameters of each $4 \times 2 \times 1$ illite supercell are $\mathrm{a}=21.14 \AA, \mathrm{b}=18.35 \AA, \mathrm{c}=9.79 \AA$; $\alpha=91^{\circ}, \beta=100^{\circ}, \gamma=90^{\circ}$.

Montmorillonite models were created with a unit cell of $a=5.16 \AA, b=8.97 \AA, c=13.61 \AA$; $\alpha=91.2^{\circ}, \beta=100.5^{\circ}, \gamma=89.6^{\circ}$, leaving enough space in the interlayer for avoiding additional variables related with interlayer complexes. Supercells of $2 \times 2 \times 1$ were generated by replacing one octahedral $\mathrm{Al}^{3+}$ by $\mathrm{Mg}^{2+}$. Layer charge is balanced with one $\mathrm{K}^{+}$cation per supercell. Two montmorillonite models were created: One with the salt $\mathrm{K}^{+} \mathrm{B}(\mathrm{OH})_{4}{ }^{-}$in the interlayer, resulting in a simulation cell 
composition of $\left[\mathrm{B}(\mathrm{OH})_{4}^{-}\right]\left[\mathrm{K}_{2}\right]\left[\mathrm{Al}_{15} \mathrm{Mg}_{1}\right]\left[\mathrm{Si}_{32}\right] \mathrm{O}_{80}(\mathrm{OH})_{16}$, and the other with $\mathrm{B}$ replacing one tetrahedral $\mathrm{Si}$ atom and $\mathrm{Si}(\mathrm{OH})_{4}$ in the interlayer, resulting in a simulation cell composition of $\left[\mathrm{Si}(\mathrm{OH})_{4}\right]\left[\mathrm{K}_{2}\right]$ $\left[\mathrm{Al}_{15} \mathrm{Mg}_{1}\right]\left[\mathrm{Si}_{31} \mathrm{~B}_{1}\right] \mathrm{O}_{80}(\mathrm{OH})_{16}$. In the illite and montmorillonite models the effect of the presence of water molecules can be considered similar in both cases with B and without B complex for the study on which is focused this work. Then, water molecules were not included to avoid additional computational effort and convergency problems found in our preliminary calculations.

\section{Results}

\subsection{Clay Mineralogy}

XRD and TEM analyses of samples were performed to characterize the clay minerals. Although preliminary XRD data indicated that samples were mainly smectite [61], the deconvolution (using MacDiff 4.2.6) of the pattern obtained from the oriented mount after glycolation in the regions $8-11^{\circ}$ $2 \theta$ and $14-19^{\circ} 2 \theta$ showed that detrital micas and mixed-layer I-S phases are present in addition to smectite (Figure 2). I-S from all samples have similar characteristics, presenting Reichweite (R) values corresponding to both the R0 (random ordering) and R1 (nearest neighbor) ordering stages (Table 2).
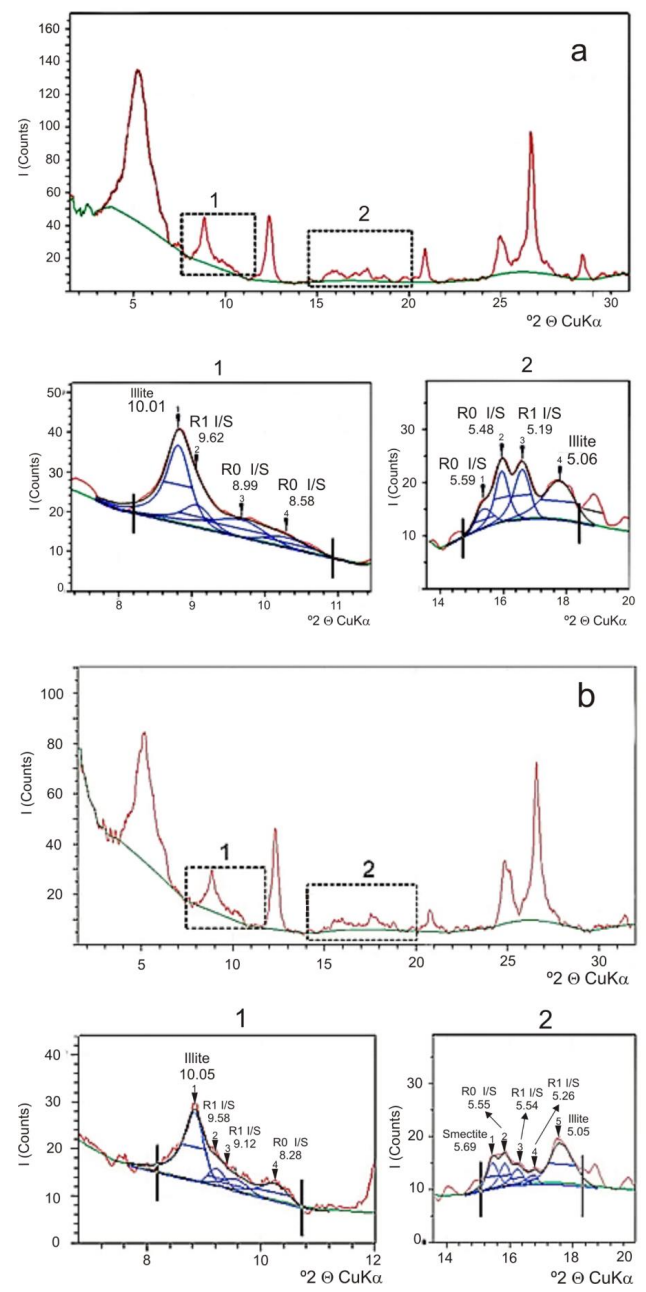

Figure 2. Example of deconvoluted XRD patterns calculated by MacDiff software in two representative samples: (a) M4 18-22 sample; and (b) M27 18-22 sample. Red line represents experimental glycolated $\mathrm{XRD}$, blue lines are deconvoluted peaks and black line represents the sum of deconvoluted peaks. Deconvoluted peaks are represented in d values in $\AA$ noted above the peaks which allow the determination of $\mathrm{R}$ type and percent illite according to [64]. 
Table 2. I-S peaks characteristic of the deconvoluted XRD patterns. Illite proportions were calculated following standard [64] procedures.

\begin{tabular}{|c|c|c|c|c|}
\hline Sample & $\mathbf{R}$ & ${ }^{\circ} 2 \theta(001 / 002) / \%$ Illite & ${ }^{\circ} 2 \theta(002 / 003) / \%$ Illite & ${ }^{\circ} \Delta 2 \theta / \%$ Illite \\
\hline \multirow{4}{*}{ M3 10-14 } & R0 & $10.31 / 10 \%$ & $15.75 / 10 \%$ & $5.44 / 10 \%$ \\
\hline & R0 & $9.85 / 45 \%$ & $16.25 / 50 \%$ & $6.40 / 45 \%$ \\
\hline & $\mathrm{R} 1$ & $9.17 / 80 \%$ & $16.83 / 75 \%$ & $7.66 / 75 \%$ \\
\hline & Illite & 8.78 & 17.61 & 8.93 \\
\hline \multirow{4}{*}{ M4 18-22 } & R0 & $10.29 / 10 \%$ & $15.83 / 15 \%$ & $5.54 / 15 \%$ \\
\hline & R0 & $9.82 / 45 \%$ & $16.16 / 45 \%$ & $6.34 / 45 \%$ \\
\hline & R1 & $9.18 / 80 \%$ & $17.07 / 80 \%$ & $7.89 / 80 \%$ \\
\hline & Illite & 8.83 & 17.51 & 8.68 \\
\hline \multirow{3}{*}{ M8 58-62 } & R0 & $10.32 / 10 \%$ & $15.78 / 10 \%$ & $5.46 / 10 \%$ \\
\hline & $\mathrm{R} 1$ & $9.64 / 55 \%$ & $16.61 / 60 \%$ & $6.97 / 60 \%$ \\
\hline & Illite & 8.84 & 17.72 & 8.88 \\
\hline \multirow{5}{*}{ M12 66-70 } & R0 & $10.35 / 10 \%$ & $15.82 / 10 \%$ & $5.47 / 10 \%$ \\
\hline & R0 & $9.99 / 40 \%$ & $16.04 / 35 \%$ & $6.05 / 35 \%$ \\
\hline & $\mathrm{R} 1$ & $9.54 / 65 \%$ & $16.70 / 60 \%$ & $7.16 / 65 \%$ \\
\hline & $\mathrm{R} 1$ & $9.30 / 75 \%$ & $16.97 / 75 \%$ & $7.67 / 75 \%$ \\
\hline & Illite & 8.89 & 17.73 & 8.84 \\
\hline \multirow{4}{*}{ M14 132-138 } & R0 & $10.22 / 15 \%$ & $15.86 / 15 \%$ & $5.64 / 15 \%$ \\
\hline & $\mathrm{R} 1$ & $9.78 / 50 \%$ & $16.48 / 55 \%$ & $6.70 / 55 \%$ \\
\hline & $\mathrm{R} 1$ & $9.36 / 75 \%$ & $16.90 / 75 \%$ & $7.54 / 75 \%$ \\
\hline & Illite & 8.82 & 17.56 & 8.74 \\
\hline \multirow{3}{*}{ M25 34-38 } & R1 & $9.72 / 55 \%$ & $16.45 / 55 \%$ & $6.73 / 55 \%$ \\
\hline & $\mathrm{R} 1$ & $9.16 / 80 \%$ & $17.04 / 80 \%$ & $7.88 / 80 \%$ \\
\hline & Illite & 8.73 & 17.71 & 8.98 \\
\hline \multirow{3}{*}{ M26 50-54 } & R0 & $10.23 / 15 \%$ & $15.82 / 15 \%$ & $5.59 / 15 \%$ \\
\hline & $\mathrm{R} 1$ & $9.74 / 55 \%$ & $16.44 / 55 \%$ & $6.70 / 55 \%$ \\
\hline & Illite & 8.79 & 17.65 & 8.86 \\
\hline \multirow{4}{*}{ M27 18-22 } & R0 & $10.17 / 25 \%$ & $15.96 / 25 \%$ & $5.79 / 25 \%$ \\
\hline & $\mathrm{R} 1$ & $9.68 / 55 \%$ & $16.40 / 55 \%$ & $6.72 / 55 \%$ \\
\hline & $\mathrm{R} 1$ & $9.22 / 75 \%$ & $16.85 / 75 \%$ & $7.63 / 75 \%$ \\
\hline & Illite & 8.83 & 17.53 & 8.70 \\
\hline \multirow{4}{*}{ M29 106-110 } & R0 & $10.05 / 30 \%$ & $15.99 / 30 \%$ & $5.94 / 30 \%$ \\
\hline & $\mathrm{R} 1$ & $9.74 / 55 \%$ & $16.32 / 55 \%$ & $6.58 / 55 \%$ \\
\hline & $\mathrm{R} 1$ & $9.19 / 80 \%$ & $17.11 / 80 \%$ & $7.92 / 80 \%$ \\
\hline & Illite & 8.86 & 17.82 & 8.96 \\
\hline \multirow{3}{*}{ C3 32-33 } & R0 & $10.30 / 10 \%$ & $15.80 / 10 \%$ & $5.50 / 10 \%$ \\
\hline & R0 & $9.76 / 50 \%$ & $16.28 / 50 \%$ & $6.52 / 50 \%$ \\
\hline & Illite & 8.87 & 17.81 & 8.94 \\
\hline \multirow{3}{*}{ C4 36-37 } & R0 & $10.09 / 30 \%$ & $15.97 / 25 \%$ & $5.88 / 25 \%$ \\
\hline & $\mathrm{R} 1$ & $9.81 / 45 \%$ & $16.29 / 50 \%$ & $6.48 / 50 \%$ \\
\hline & Illite & 8.84 & 17.74 & 8.9 \\
\hline \multirow{3}{*}{ C7 36-37 } & R0 & $10.06 / 30 \%$ & $15.98 / 25 \%$ & $5.92 / 30 \%$ \\
\hline & R1 & $9.55 / 60 \%$ & $16.58 / 60 \%$ & $7.03 / 60 \%$ \\
\hline & Illite & 8.92 & 17.74 & 8.82 \\
\hline \multirow{3}{*}{ C8 23-24 } & R0 & $10.07 / 30 \%$ & $15.99 / 30 \%$ & $5.92 / 30 \%$ \\
\hline & $\mathrm{R} 1$ & $9.68 / 55 \%$ & $16.52 / 55 \%$ & $6.84 / 55 \%$ \\
\hline & Illite & 8.97 & 17.69 & 8.72 \\
\hline \multirow{3}{*}{ C9 84-85 } & R0 & $10.28 / 15 \%$ & $15.84 / 15 \%$ & $5.56 / 15 \%$ \\
\hline & R1 & $9.67 / 55 \%$ & $16.46 / 55 \%$ & $6.79 / 55 \%$ \\
\hline & Illite & 8.87 & 17.75 & 8.88 \\
\hline \multirow{2}{*}{ C10 27-28 } & $\mathrm{R} 1$ & $9.18 / 80 \%$ & $17.06 / 80 \%$ & $7.88 / 80 \%$ \\
\hline & Illite & 8.87 & 17.81 & 8.94 \\
\hline & R0 & $10.22 / 20 \%$ & $15.83 / 20 \%$ & $5.61 / 20 \%$ \\
\hline & R0 & $9.81 / 50 \%$ & $16.35 / 50 \%$ & $6.54 / 50 \%$ \\
\hline A2 48-50 & $\mathrm{R} 1$ & $9.31 / 75 \%$ & $16.92 / 75 \%$ & $7.61 / 75 \%$ \\
\hline & Illite & 8.81 & 17.69 & 8.88 \\
\hline & R0 & $10.08 / 30 \%$ & $15.98 / 25 \%$ & $5.90 / 30 \%$ \\
\hline & $\mathrm{R} 1$ & $9.66 / 55 \%$ & $16.47 / 55 \%$ & $6.81 / 55 \%$ \\
\hline A4 48-50 & $\mathrm{R} 1$ & $9.33 / 75 \%$ & $17.04 / 80 \%$ & $7.71 / 75 \%$ \\
\hline & Illite & 8.90 & 17.80 & 8.90 \\
\hline A8 $110-111$ & R0 & $9.77 / 50 \%$ & $16.19 / 45 \%$ & $6.42 / 45 \%$ \\
\hline A8 110-111 & Illite & 8.84 & 17.78 & 8.94 \\
\hline & R0 & $9.94 / 40 \%$ & $16.12 / 40 \%$ & $6.18 / 40 \%$ \\
\hline A $1426-30$ & Illite & 8.79 & 17.36 & 8.57 \\
\hline
\end{tabular}


The deconvolution of the peaks corresponding to 001/002 and 002/003 reflections into small peaks allows estimating the proportion of illite in each $I / S$, because each $d$ value corresponds to R-ordering type.

A detailed TEM study combining chemistry and the imagery of individual clay-mineral particles on the holey carbon grid showed the expected morphological differences between the smectite and I-S: smectite displayed typical aggregates and flakes of irregular and wavy outlines and I-S showed individual crystals with more euhedral shapes and clear outlines (Figure 3). These morphologies are consistent with previous TEM observations on smectite illitization [85]. Kaolin hexagonal particles and palygorskite fibers were also present in the samples in minor amounts (Figure 3).
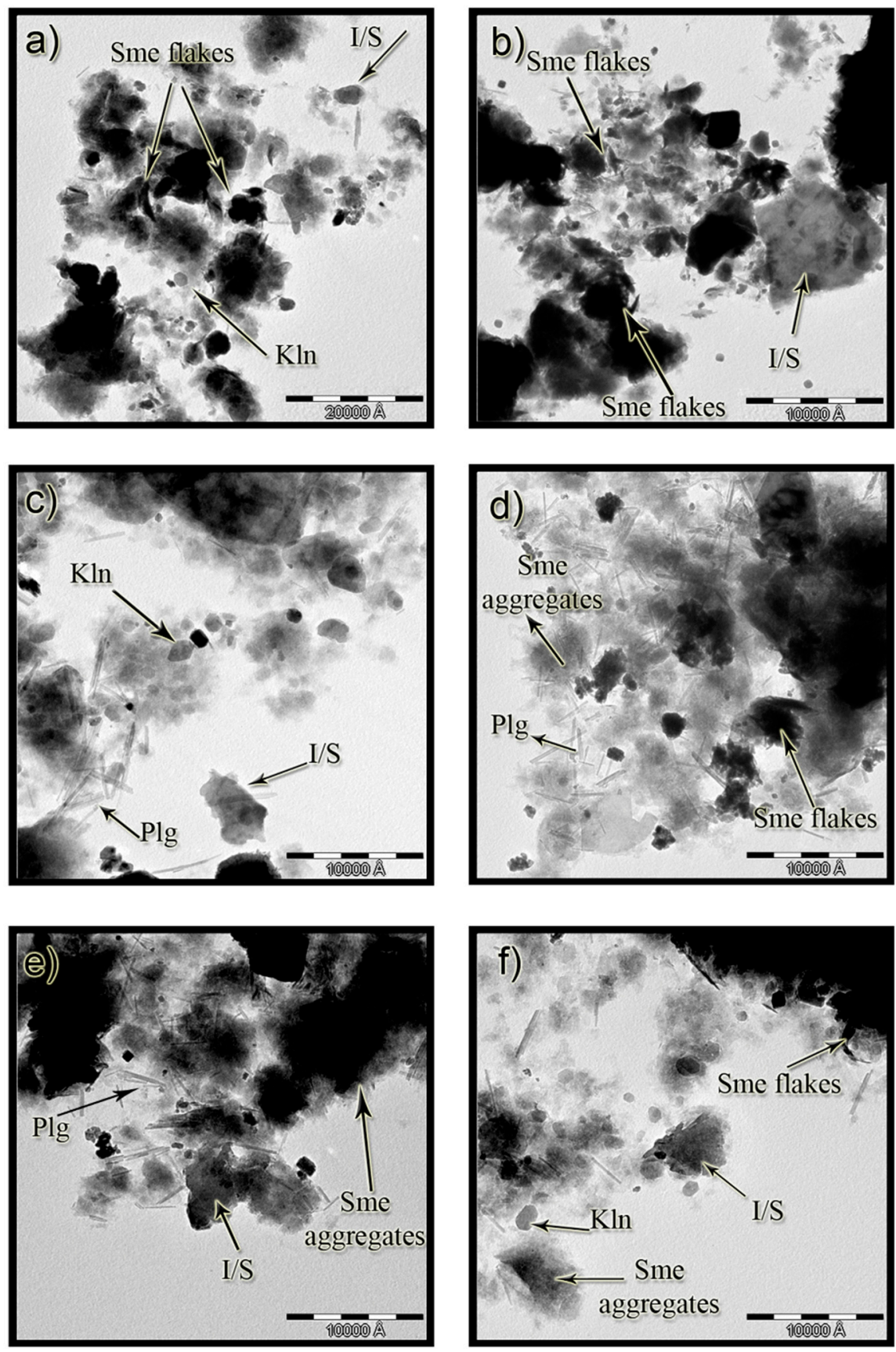

Figure 3. TEM micrographs of the major phases present. Sme, Smectite; Kln, Kaolinite; Plg, Palygorskite; I/S, Illite-smectite interstratified. Samples: (a) M8 58-62; (b) M12 50-54; (c) C9 84-85; (d) C8 23-24; (e) M25 34-38; and (f) A2 48-50. 
Figure 4 shows compositional variation of individual clay crystals determined by analytical electron microscopy (AEM). Figure 4a is a plot of tetrahedral Al content vs. interlayer K, showing trends that relate to particle morphology as defined by [85]. Chemical ranges correlate with TEM observations, where smectite flakes, aggregates, round and polygonal particles are characterized. The substitution of $\mathrm{Al}$ by $\mathrm{Fe}$ in the octahedral sites provides a well-defined negative relationship between these two elements (Figure $4 b$ ).
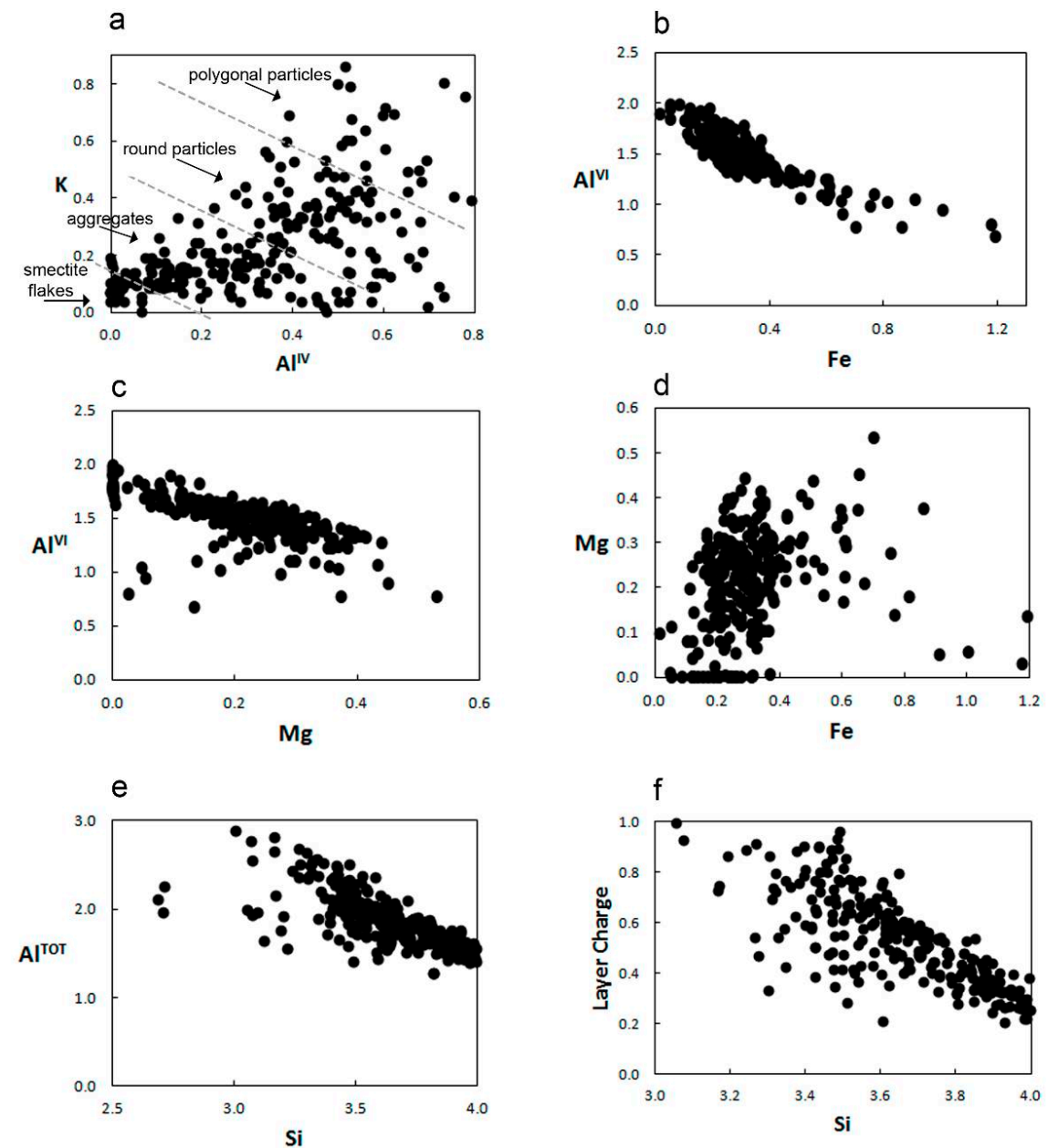

Figure 4. Compositional variation of the smectites and I-S phases normalizing to $10 \mathrm{O}$ atoms and 2 $(\mathrm{OH})$ groups per structural formula. (a) K content vs. tetrahedral $\mathrm{Al}\left(\mathrm{Al}^{\mathrm{IV}}\right)$; (b) Tetrahedral Aluminum $\left(\mathrm{Al}^{\mathrm{IV}}\right)$ vs. Fe content; (c) Tetrahedral Aluminum $\left(\mathrm{Al}^{\mathrm{IV}}\right)$ vs. Mg content; (d). Mg vs. Fe content; (e) Total $\mathrm{Al}\left(\mathrm{Al}^{\mathrm{TOT}}\right)$ vs. Si content; (f) Layer charge vs Si.

A similar negative relationship is also observed between $\mathrm{Al}$ and $\mathrm{Mg}$ (Figure 4c). No significant trends were found between $\mathrm{Si}$ and $\mathrm{Fe}$ or $\mathrm{Si}$ and $\mathrm{Mg}$ (not shown). However, there is a poorly defined positive relationship between Fe and $\mathrm{Mg}$ (Figure $4 \mathrm{~d}$ ). There is a negative relationship between $\mathrm{Al}$ TOT and Si (Figure 4e), indicating the generation of tetrahedral charge. Figure $4 \mathrm{f}$ shows the relationship between layer charge and Si content, where mainly beidellitic samples have more than half of the layer charge produced by tetrahedral substitutions. However, montmorillonite samples can be also represented by larger amounts of $\mathrm{Si}$.

The plot of data in MR3-2R3-3R2 diagram [86] (Figure 5) clearly shows different chemical ranges in the samples analyzed, from montmorillonite and beidellite to illite compositions. The presence of I-S phases is represented by multiple points with compositions between smectite and illite. 


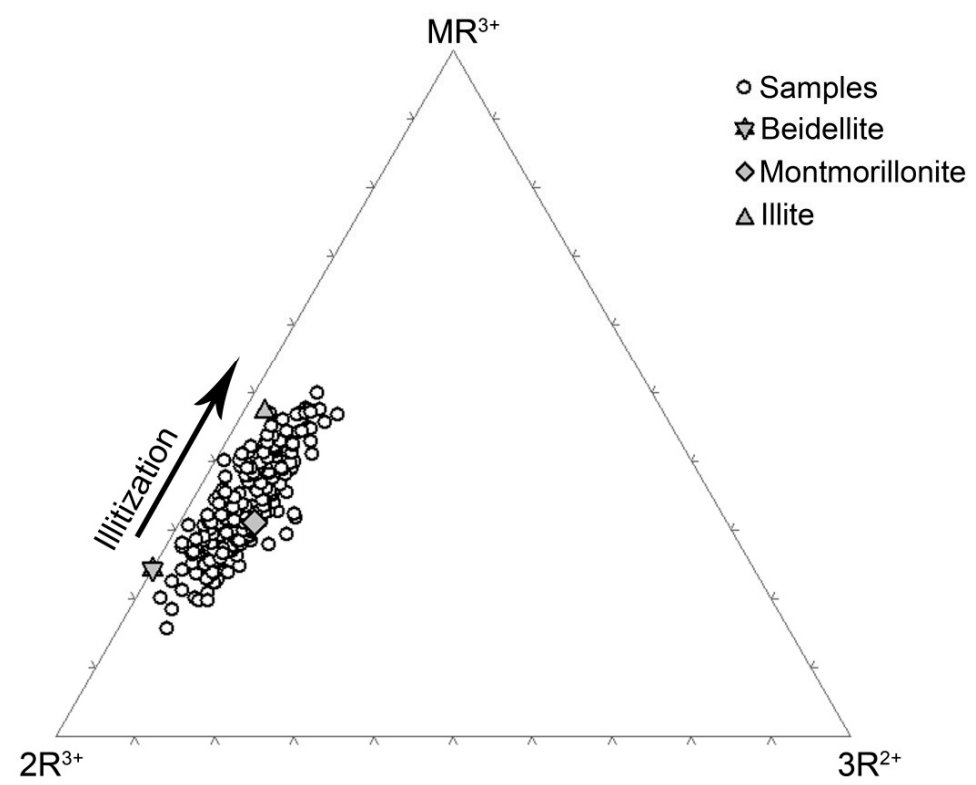

Figure 5. AEM chemical data of the smectite illitization process represented in a MR3-2R3-3R2 diagram [86]. $\mathrm{MR}^{3+}:\left(\mathrm{Na}^{+}+\mathrm{K}^{+}+2 \mathrm{Ca}^{2+}+2 \mathrm{Mg}^{2+}\right) ; 2 \mathrm{R}^{3+}:\left(\mathrm{Al}^{3+}+\mathrm{Fe}^{3+}-\mathrm{MR}^{3+}\right) / 2 ; 3 \mathrm{R}_{2+}:\left(\mathrm{Fe}_{2}{ }^{+}+\mathrm{Mg}^{2+}\right.$ $\left.+\mathrm{Mn}^{2+}\right) / 3$. Modified from [87].

\subsection{Boron Content and Isotopes}

The bulk B-content of the clay minerals studied range from 97 to $146 \mathrm{ppm}$. Cation exchanged (xc) samples contain slightly less B than the bulk mannitol washed (mw) samples, due to the loss of interlayer B after cation exchange. This implies that most of the B in the clay is fixed in the tetrahedral layer (structurally bound) and only minor amounts of B were held in the I-S interlayer. Figure 6 shows that there are no spatial correlations between $\delta^{11} \mathrm{~B}$ values and mud volcanoes locations or bathymetric depth.

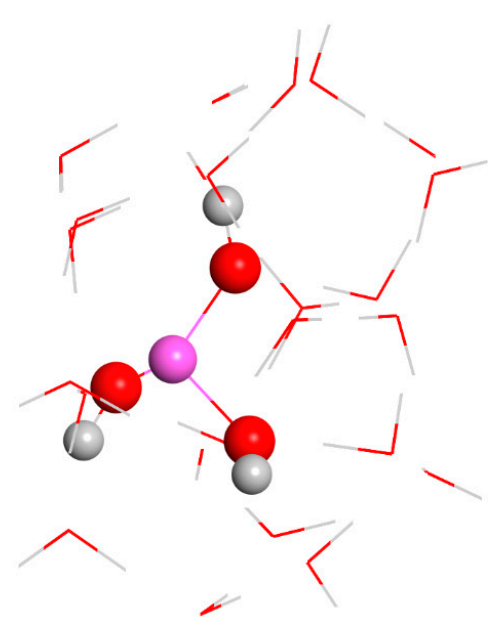

(a)

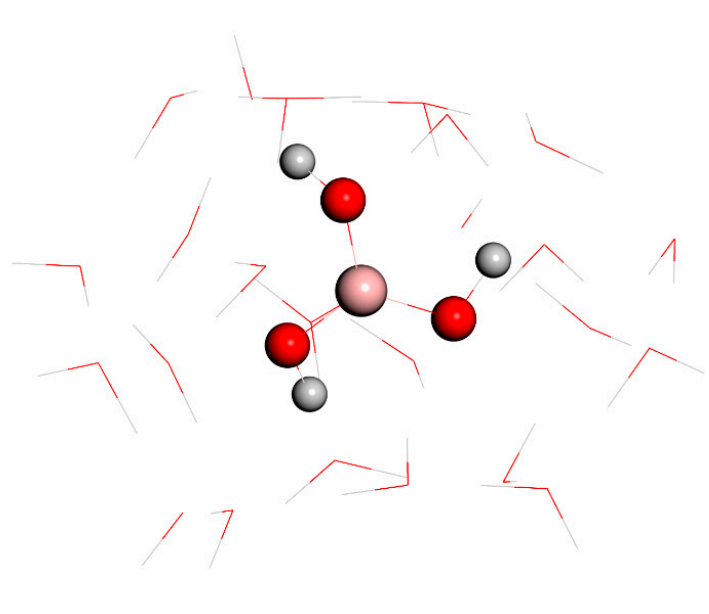

(b)

Figure 6. Optimized structures of the hydrated $\mathrm{Al}(\mathrm{OH})_{3}(\mathbf{a})$ and $\mathrm{B}(\mathrm{OH})_{3}(\mathbf{b})$ models. $\mathrm{H}, \mathrm{O}, \mathrm{Al}$ and $\mathrm{B}$ atoms are represented in light-gray, red, pink and orange, respectively. Water molecules are represented as sticks.

\subsection{Computational Modeling}

Geometry optimizations of Al-illite and B-illite models were performed at constant and variable volumes. The lattice parameters and the main geometrical features of the optimized structures are 
consistent with experimental values (Table 3), with a mean basal d(001) value of $10.02 \AA$ for Al-illite and $10.03 \AA$ for B-illite. The main geometrical features of the hydrated $\mathrm{Al}(\mathrm{OH})_{3}$ and $\mathrm{B}(\mathrm{OH})_{3}$ models (Figure 6) are presented in Table 4. This table shows average values being smaller bond distances in $\mathrm{B}(\mathrm{OH})_{3}$ molecule than in $\mathrm{Al}(\mathrm{OH})_{3}$. These bond lengths are consistent with $\mathrm{B}-\mathrm{O}$ and $\mathrm{Al}-\mathrm{O}$ distances observed in the B-illite model described in Table 4. In the B hydrated complexes, the structure is highly symmetric with the cation and $\mathrm{O}$ atoms in the same plane according to previous studies at gas phase [88], whereas the $\mathrm{H}$ atoms are twisted to a different plane and oriented towards the vicinal $\mathrm{O}$ atom of the same molecule. However, in the $\mathrm{Al}(\mathrm{OH})_{3}$ hydrated complex, the $\mathrm{Al}$ cation forms a pyramidal form with the $\mathrm{O}$ atoms; similar non-planar configurations have been reported in $\mathrm{Al}$ hydrates previously [89]. There are strong $\mathrm{H}$ bonding interactions between the metal hydroxides and the surrounding water molecules. Hence, different $\mathrm{B}-\mathrm{O}$ bond lengths are found $\mathrm{d}(\mathrm{B}-\mathrm{O} 1)=1.355 \AA$, $\mathrm{d}(\mathrm{B}-\mathrm{O} 2)=1.371 \AA \AA$ and $\mathrm{d}(\mathrm{B}-\mathrm{O} 3)=1.394 \AA$ and consequently different $\mathrm{BO}-\mathrm{H}$ bond lengths are found, $\mathrm{d}(\mathrm{O} 1-\mathrm{H})=1.023 \AA, \mathrm{d}(\mathrm{O} 2-\mathrm{H})=1.004 \AA$ and $\mathrm{d}(\mathrm{O} 3-\mathrm{H})=1.002 \AA$. This can be explained due to a strong $\mathrm{H}$ bond with one water molecule $\mathrm{d}(\mathrm{O} 1 \mathrm{H} \ldots \mathrm{Ow})=1.563 \AA$, $\mathrm{d}(\mathrm{O} 2 \mathrm{H} \ldots \mathrm{Ow})=1.633 \AA, \mathrm{d}(\mathrm{BO} 2 \ldots \mathrm{Hw})=$ $1.495 \AA, \mathrm{d}(\mathrm{O} 3 \mathrm{H} \ldots \mathrm{Ow})=1.795 \AA$, Some correlation can be observed: a stronger H bond, a longer $\mathrm{O}-\mathrm{H}$ bond and a stronger $\mathrm{B}-\mathrm{O}$ bond length is. A similar effect is observed in $\mathrm{Al}(\mathrm{OH})_{3}$ with $\mathrm{d}(\mathrm{Al}-\mathrm{O} 1)$ $=1.743 \AA, \mathrm{d}(\mathrm{Al}-\mathrm{O} 2)=1.787 \AA$ and $\mathrm{d}(\mathrm{Al}-\mathrm{O} 3)=1.836 \AA$ and also strong $\mathrm{H}$ bonds $\mathrm{d}(\mathrm{O} 1 \mathrm{H} \ldots \mathrm{Ow})=$ $1.554 \AA, \mathrm{d}(\mathrm{O} 2 \mathrm{H} \ldots \mathrm{Ow})=1.640 \AA$ and $\mathrm{d}(\mathrm{AlO} 2 \ldots \mathrm{Hw})=1.262 \AA, \mathrm{d}(\mathrm{O} 3 \mathrm{H} \ldots \mathrm{Ow})=1.567 \AA$. During the optimizations, proton exchanges are observed by dissociation of water molecules, according to previous works on $\mathrm{Al}$ hydrates [90].

Table 3. Cell parameters and select interatomic distances of Al-illite and B-illite unit cells (distances in $\AA$ and angles in ${ }^{\circ}$ ).

\begin{tabular}{cccc}
\hline Features & Exp $^{\text {a }}$ & Al-illite & B-Illite \\
\hline$a$ & 5.22 & 5.24 & 5.24 \\
$b$ & 9.02 & 9.10 & 9.08 \\
$c$ & 10.07 & 10.09 & 10.08 \\
$d(001)$ & 10.02 & 10.02 & 10.03 \\
$\alpha$ & 90.0 & 101.1 & 101.1 \\
$\beta$ & 95.7 & 95.8 & 95.9 \\
$\gamma$ & 90.0 & 89.9 & 89.9 \\
$d(\mathrm{Si}-\mathrm{O})$ & 1.65 & 1.67 & 1.67 \\
$\mathrm{~d}(\mathrm{~B}-\mathrm{O})$ & & & 1.48 \\
$\mathrm{~d}\left(\mathrm{Al} \mathbf{V}_{-}-\mathrm{O}\right)$ & 1.96 & 1.95 & 1.94 \\
$\mathrm{~d}(\mathrm{O}-\mathrm{H})$ & & 0.97 & 0.97 \\
\hline & &
\end{tabular}

Table 4. Interatomic distances of hydrated $\mathrm{Al}(\mathrm{OH})_{3}$ and $\mathrm{B}(\mathrm{OH})_{3}$ models (distances in $\AA$ and angles in ${ }^{\circ}$ ).

\begin{tabular}{cccc}
\hline \multicolumn{4}{c}{ Average Features } \\
\hline Hydrated Al(OH) $)_{3}$ Model & Hydrated B(OH) & Model \\
\hline $\mathrm{d}(\mathrm{Al}-\mathrm{O})$ & 1.75 & $\mathrm{~d}(\mathrm{~B}-\mathrm{O})$ & 1.37 \\
$\mathrm{~d}(\mathrm{O}-\mathrm{H})$ & 1.01 & $\mathrm{~d}(\mathrm{O}-\mathrm{H})$ & 1.01 \\
$\alpha(\mathrm{Al}-\mathrm{O}-\mathrm{H})$ & 120.11 & $\alpha(\mathrm{B}-\mathrm{O}-\mathrm{H})$ & 110.83 \\
$\mathrm{~d}\left(\mathrm{H}_{\mathrm{w}}-\mathrm{O}_{\mathrm{w}}\right)$ & 1.05 & $\mathrm{~d}\left(\mathrm{H}_{\mathrm{w}}-\mathrm{O}_{\mathrm{w}}\right)$ & 1.05 \\
$\mathrm{~d}\left(\mathrm{H}_{\mathrm{w}} \ldots \mathrm{O}_{\mathrm{w}}\right)$ & 1.50 & $\mathrm{~d}\left(\mathrm{H}_{\mathrm{w}} \ldots \mathrm{O}_{\mathrm{w}}\right)$ & 1.55 \\
$\mathrm{~d}\left(\mathrm{H}_{\mathrm{Al}} \ldots \mathrm{O}_{\mathrm{w}}\right)$ & 1.76 & $\mathrm{~d}\left(\mathrm{H}_{\mathrm{B}} \ldots \mathrm{O}_{\mathrm{w}}\right)$ & 1.67 \\
\hline
\end{tabular}


The optimization energies of the two illite models (Figure 7) are compared with the energies of the hydrated $\mathrm{Al}(\mathrm{OH})_{3}$ and $\mathrm{B}(\mathrm{OH})_{3}$ models by proposing the next reaction:

$$
\mathrm{U}_{\text {Al-illite }}+\mathrm{U}_{\mathrm{B}(\mathrm{OH}) 3} \leftrightarrow{ }_{\text {B-illite }}+\mathrm{U}_{\mathrm{Al}(\mathrm{OH}) 3}
$$

where $U$ is the internal energy of the system. Our results shows that $\mathrm{UAl}-\mathrm{illite}+\mathrm{UB}(\mathrm{OH})_{3}$ is less stable $(-105751.2580 \mathrm{eV})$ than $\mathrm{UB}-\mathrm{illite}+\mathrm{UAl}(\mathrm{OH})_{3}(-105751.6327 \mathrm{eV})$ in $36.7 \mathrm{KJ} / \mathrm{mol}$. This means that the fixation of $\mathrm{B}$ on the illite tetrahedral layer instead of $\mathrm{Al}$ atoms is energetically favorable.

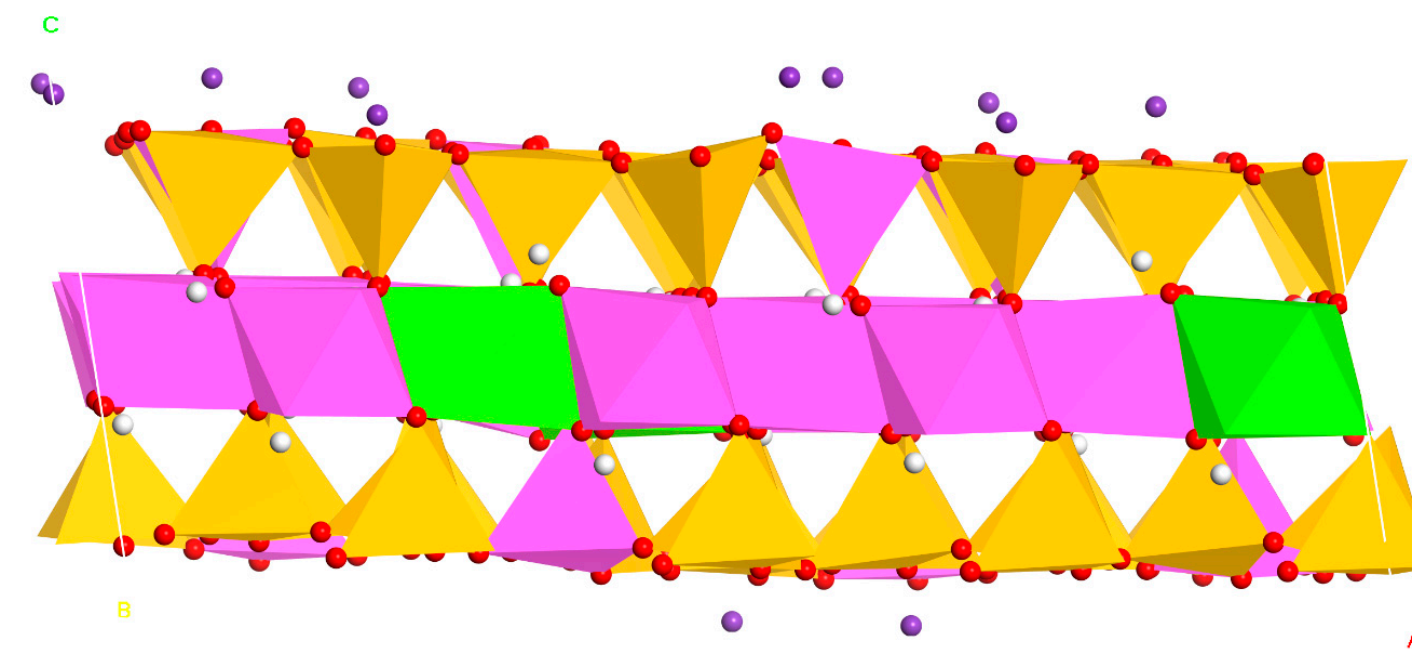

(a)

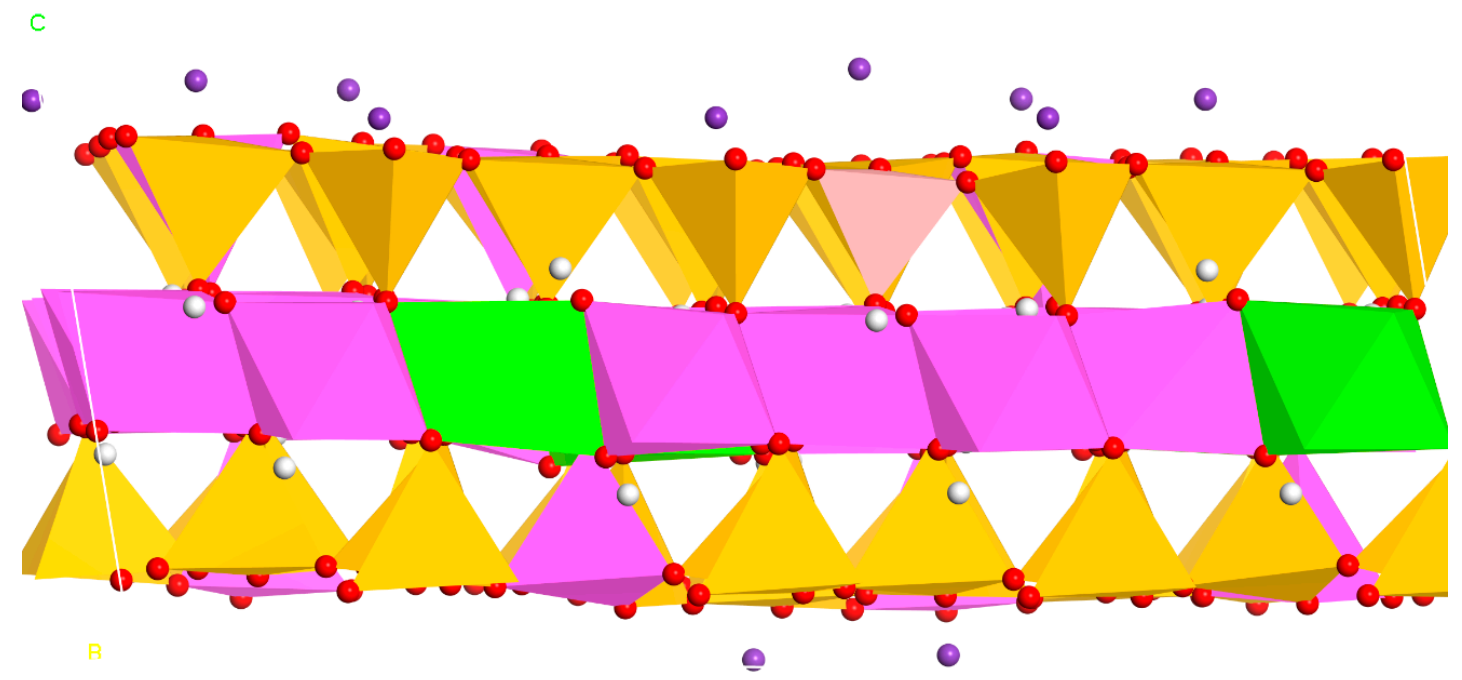

(b)

Figure 7. Optimized crystal structure of: the Al-illite model (a); and the B-illite model (b). The $\mathrm{H}, \mathrm{O}$ and $\mathrm{K}$ atoms are represented in light-gray, red and fuchsia, respectively. The $\mathrm{Si}, \mathrm{Al}, \mathrm{Mg}$ and $\mathrm{B}$ polygons are in yellow, pink, green and orange, respectively.

The optimization energies of the two montmorillonite models (Figure 8) are also compared, showing that montmorillonite with tetrahedral B is more stable $(-48414.1023 \mathrm{eV})$ than montmorillonite with interlayer $\mathrm{B}(\mathrm{OH})_{4}{ }^{-}(-48413.1163 \mathrm{eV})$, again proving that the incorporation of $\mathrm{B}$ in the tetrahedral layer is a energetically favorable process. Furthermore, in the optimized model of montmorillonite with interlayer $\mathrm{K}^{+} \mathrm{B}(\mathrm{OH})_{4}^{-}$, it can be noticed that this salt is dissociated in $\mathrm{B}(\mathrm{OH})_{3}$ and $\mathrm{K}^{+}(\mathrm{OH})^{-}$. 
The $\mathrm{B}(\mathrm{OH})_{3}$ forms a $\mathrm{H}$ bond with basal tetrahedral $\mathrm{O}$ atoms, $\mathrm{d}(\mathrm{O} \ldots \mathrm{H})=1.75 \AA$, and with the $\mathrm{OH}$ anion $\mathrm{d}(\mathrm{O} \ldots \mathrm{H})=1.68 \AA$. Our energetic result is consistent with previous empirical studies [92] that indicated $\mathrm{B}(\mathrm{OH})_{3}$ dominates in the I-S interlayer space.

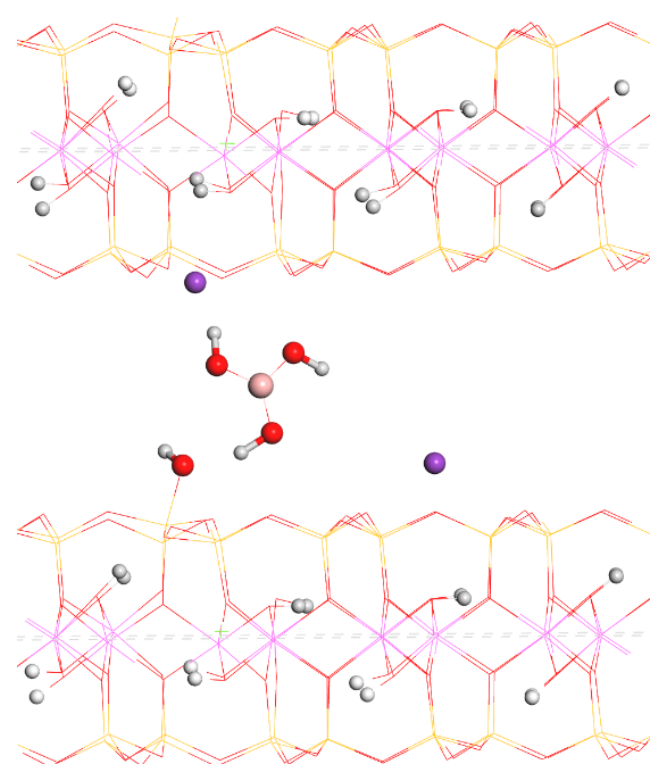

(a)
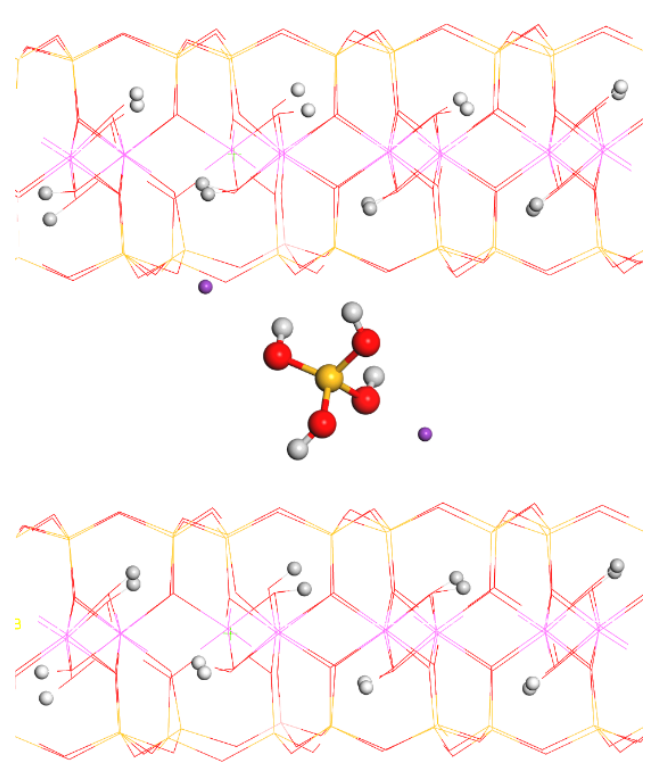

(b)

Figure 8. Optimized crystal structures of montmorillonite with: interlayer $\mathrm{B}(\mathrm{OH})_{3}$ model (a); and montmorillonite with tetrahedral $\mathrm{B}$ and $\mathrm{Si}(\mathrm{OH})_{4}$ in the interlayer model (b). The $\mathrm{H}, \mathrm{O}, \mathrm{K}$, $\mathrm{Si}, \mathrm{Al}$ and $\mathrm{B}$ are represented in light-grey, red, fuchsia, pink and orange, respectively.

Further calculations will be performed exploring these phyllosilicate models with different moisture grade (water molecules) and several pressure conditions (sediments environments) to complete this study but they are out of the scope of the present work.

\section{Discussion}

\subsection{Clay Mineralogy and Diagenetic Evolution of Deep Sediments in the Gulf of Cádiz}

TEM images and XRD data show that smectite and interstratified illite-smectite (I-S) are present as well as other clay minerals such as detrital mica, kaolin plates and palygorskite. The chemical analyses conducted on individual particles, indicate that all smectite and I-S phases are dioctahedral, with $\mathrm{Al}$ as the main octahedral cation. Notably, Si from the smectite layers in the mixed-layered I-S decreases as illitization progresses (Figure 5). Focusing on the nature of interlayer cations, the compositional analysis shows a wide range of variations in the content of $\mathrm{K}, \mathrm{Na}, \mathrm{Ca}$ and $\mathrm{Mg}$, but the dominant cation is $\mathrm{K}$. There is a good correlation between the interlayer $\mathrm{K}$ content and tetrahedral Al (Figure 4a). From this plot, together with the observations of these morphologies by TEM (Figure 3), it can be inferred that the increase in the illitization produces morphological and chemical changes that increases $\mathrm{K}$ and tetrahedral $\mathrm{Al}$ in clay particles. This is supported by the percentage of illite in I-S and Reichweite (R) estimations (Table 2 and Figure 5).

Some smectite-illite transformation characteristics can be observed in the $\mathrm{MR}^{3+}-2 \mathrm{R}^{3+}-3 \mathrm{R}^{2+}$ ternary diagram (Figure 5) [86]. In this diagram, the chemical composition of clay particles is represented together with ideal compositions of the discrete phases involved in the transformation (montmorillonite, beidellite and illite). The dioctahedral character of the phases involved in the illitization process is represented by the distance of the data from the $3 R^{2+}$ apex. Furthermore, for illite-rich phases, an increase in the layer charge and interlayer cations can be seen, represented by the trend of the data towards the $\mathrm{MR}^{3+}$ apex. 
All the clay geochemical trends are related to prograde diagenetic changes, where the dominant clay minerals provide clues about the burial/thermal history of sedimentary basins [19]. The reduction of expandable layers or the smectite-illite transformation processes have been related to the evolution of petroleum systems, as illitization of smectite overlaps the oil window [93-98], as discussed by numerous papers addressing the potential for reaction through solid state transformation or dissolution/precipitation mechanisms $[17,19,61,85]$. Although the coexistence of different I-S phases in a sample can correlate with a prograde evolution in a diagenetic sequence, in this study, the physical mixture of clay minerals may come from different stratigraphic units as a result of fluid expulsion during emplacement of the mud volcano [13]. Nevertheless, morphological changes observed by TEM (polygonal to euhedral) point to similar mechanisms described previously [85] in a series of experimental hydrothermal conditions as seen by X-ray diffraction and TEM, where they suggest illitization mechanism driven by dissolution/crystallization processes.

MV clay mineral samples in this study, with $\delta^{11} \mathrm{~B}$ values ranging from +2.2 to 12.7 and an average of $-2.2 \%$ o fixed-B abundances, are relatively high, $82-145$ ppm. Again, a precipitation process is the most probable mechanism to incorporate $B$ in the tetrahedral layer of illite as described previously by the authors of $[68,99]$, showing that, during diagenesis, as temperatures approach $120{ }^{\circ} \mathrm{C}$, B-adsorption becomes negligible and substitution of Si by B occurs as illite forms [100]. Molecular models presented in this work are in agreement with this statement, as these calculations prove that it is energetically favorable for $\mathrm{B}$ to reside in the tetrahedral sites of illite. Although B-O bonds in the tetrahedral layer are shorter $(1.48 \AA)$ than Al-O and Si-O bonds (1.78 and $1.67 \AA$, respectively), the lattice parameters of B-illite models are similar to the Al-illite model and to the experimental illite values, meaning that the incorporation of B in tetrahedral sites has no effect on the crystal structure.

Boron geochemistry has been studied recently in different environments as an indicator of fluid circulation and diagenetic grade. A set of samples from different mud volcanoes around the world as indicators of progressive diagenesis show a good correlation between B contents and $\delta^{11} \mathrm{~B}$ isotopic values [101,102], although these studies did not carefully separate tetrahedral B from interlayer (trigonal) B. Besides $\mathrm{B}$, the uptake of $\mathrm{N}$ in illite (as $\mathrm{NH}_{4}{ }^{+}$substituting for $\mathrm{K}^{+}$) increases during diagenesis as illitization proceeds and has been studied in hydrocarbon-bearing sedimentary basins suggesting a kerogen source for both elements [32,103-105]

The nature of clay and clasts present in the mud breccia of the Gulf of Cádiz mud volcanoes can be used to infer the possible depth of the underlying units [42,56]. In Yuma mud volcano in the Moroccan margin, more than 200 clasts from the mud breccia were studied [106], displaying a very complex mixture of material from the sedimentary successions. The reconstructed sedimentary succession showed sediments at least as old as Eocene, with the presence of several clayey units Miocene in age (Aquitanian and Tortonian).

The detailed clay mineral characterization and the chemical composition made in this study indicates that although I-S content can vary among the mud volcanoes, the clay mineralogy is similar to that found in Tertiary units (Miocene in age) common in Mediterranean Messinian sediments. The Messinian clay minerals taken in DSDP legs 13 and 42A contained large amounts of smectite and are constant throughout the Mediterranean Basin [107,108]. Similar results were found by [109] and [110] in the Lower Messinian in Sicily or by [111] in the Upper Cenomanian-Turonian sediments in the high Atlas in Morocco. In addition, clays (dioctahedral smectite and illite) are a common component in the Miocene-Pliocene lithostratigraphic formations (Gibraleon clays) of the lower Guadalquivir Basin [112-114].

Based on the $\delta^{11} \mathrm{~B}$ values of I-S in MVs of the Gulf of Cádiz (-12.7\% to $+5.3 \%$; Table 5), the average clays equilibrated in fluid with $\delta^{11} \mathrm{~B}<10 \%$, (calculated using the mineral-water fractionation factor $1000 \ln \alpha_{\text {min-water }}=3.28-10.35(1000 / \mathrm{T})$; [33], which is significantly more ${ }^{10} \mathrm{~B}$-enriched than seawater $(+39 \%$ ). We interpret the B-isotope composition of the I-S in MVs of the Gulf of Cádiz to result from illitization of the smectite-rich sediments, probably from Messinian sources over a range of temperature during organic maduration of primary source rocks $\left(\sim 80-150^{\circ} \mathrm{C}\right)$. Hydrocarbon-related fluids generated 
at temperatures of methane production $\left(\sim 150^{\circ} \mathrm{C}\right)$ are enriched in ${ }^{10} \mathrm{~B}[24,115]$, thus hydrocarbon related fluids are the likely source of isotopically light B in I-S in all the studied samples, from north to south and from the shelf to $1639 \mathrm{~m}$ depth. There are no mineralogical sources in these sediments that could be a source of such high concentrations of ${ }^{10} \mathrm{~B}$-enriched fluids.

Table 5. Boron isotope analysis. $m w$, Mannitol washed samples; $x c, \mathrm{NH}_{4} \mathrm{Cl}$ exchanged samples. Standard IMt- 1 is analyzed to determine IMF for each analytical session. This value is subtracted from the delta value. SE is standard error of the average. PE is predicted error, which is the best possible error based on counting statistics.

\begin{tabular}{|c|c|c|c|c|c|c|c|c|}
\hline Sample & Preparation & $11 / 10$ & IMF & $\delta^{11} B$ & SE \%o & PE \%o & $n$ & B (ppm) \\
\hline \multirow{2}{*}{ M3 10-14 } & $m w$ & 39.192 & -27.8 & -3 & 1.0 & 0.9 & 3 & 142 \\
\hline & $x c$ & 39.151 & -27.8 & -4 & 0.3 & 0.8 & 3 & 132 \\
\hline \multirow{2}{*}{ M4 18-22 } & $m w$ & 39.139 & -27.8 & -4.3 & 0.6 & 1.0 & 3 & 104 \\
\hline & $x c$ & 39.090 & -27.8 & -5.5 & 0.5 & 0.5 & 2 & 88 \\
\hline \multirow{2}{*}{ M8 58-62 } & $m w$ & 39.568 & -27.8 & 6.3 & 2.0 & 1.4 & 3 & 96 \\
\hline & $x c$ & 39.361 & -27.8 & 1.2 & 0.5 & 0.4 & 2 & 82 \\
\hline \multirow{2}{*}{$\begin{array}{l}\text { M12 } \\
66-70\end{array}$} & $m w$ & 39.163 & -27.8 & -3.7 & 0.9 & 0.5 & 2 & 99 \\
\hline & $x c$ & 39.115 & -27.8 & -4.9 & 0.1 & 0.6 & 2 & 89 \\
\hline \multirow{2}{*}{$\begin{array}{c}\text { M14 } \\
138-142\end{array}$} & $m w$ & 39.030 & -27.8 & -7 & 0.1 & 0.6 & 2 & 105 \\
\hline & $x c$ & 38.965 & -27.8 & -8.6 & 0.5 & 0.5 & 2 & 102 \\
\hline \multirow{2}{*}{$\begin{array}{c}\text { M25 } \\
34-38\end{array}$} & $m w$ & 39.305 & -24.6 & -3.4 & 0.6 & 0.4 & 2 & 137 \\
\hline & $x c$ & 39.192 & -24.6 & -6.2 & 0.6 & 0.4 & 2 & 134 \\
\hline \multirow{2}{*}{$\begin{array}{l}\text { M26 } \\
50-54\end{array}$} & $m w$ & 39.224 & -24.6 & -5.4 & 0.6 & 0.3 & 2 & 101 \\
\hline & $x c$ & 39.204 & -24.6 & -5.9 & 0.5 & 0.4 & 2 & 94 \\
\hline \multirow{2}{*}{$\begin{array}{l}\text { M27 } \\
18-22\end{array}$} & $m w$ & 39.442 & -24.6 & 0 & 0.7 & 0.3 & 2 & 146 \\
\hline & $x c$ & 39.236 & -24.6 & -5.1 & 0.8 & 0.4 & 2 & 141 \\
\hline \multirow{2}{*}{$\begin{array}{c}\text { M29 } \\
106-110\end{array}$} & $m w$ & 39.337 & -24.6 & -2.6 & 0.5 & 0.3 & 2 & 132 \\
\hline & $x c$ & 39.171 & -24.6 & -6.7 & 0.6 & 0.3 & 2 & 122 \\
\hline \multirow{2}{*}{ C3 32-33 } & $m w$ & 39.685 & -24.6 & 6 & 0.6 & 0.3 & 2 & 126 \\
\hline & $x c$ & 39.657 & -24.6 & 5.3 & 0.8 & 0.5 & 2 & 115 \\
\hline \multirow{2}{*}{ C4 36-37 } & $m w$ & 39.644 & -24.6 & 5 & 0.7 & 0.5 & 2 & 113 \\
\hline & $x c$ & 39.499 & -24.6 & 1.4 & 0.6 & 0.4 & 2 & 103 \\
\hline \multirow{2}{*}{ C7 38-39 } & $m w$ & 39.309 & -24.6 & -3.3 & 0.6 & 0.4 & 2 & 120 \\
\hline & $x c$ & 39.058 & -24.6 & -9.5 & 0.6 & 0.4 & 2 & 113 \\
\hline \multirow{2}{*}{ C8 23-24 } & $m w$ & 39.596 & -24.6 & 3.8 & 0.9 & 0.5 & 2 & 163 \\
\hline & $x c$ & 39.297 & -24.6 & -3.6 & 0.7 & 0.4 & 2 & 145 \\
\hline \multirow{2}{*}{ C9 84-85 } & $m w$ & 39.220 & -31.8 & 1.7 & 0.5 & 0.4 & 2 & 97 \\
\hline & $x c$ & 39.050 & -31.8 & -2.5 & 0.5 & 0.4 & 2 & 96 \\
\hline \multirow{2}{*}{$\begin{array}{c}\mathrm{C} 10 \\
27-28\end{array}$} & $m w$ & 39.001 & -31.8 & -3.7 & 0.6 & 0.4 & 2 & 137 \\
\hline & $x c$ & 38.892 & -31.8 & -6.4 & 0.7 & 0.4 & 2 & 121 \\
\hline \multirow{2}{*}{ A2 48-50 } & $m w$ & 38.908 & -31.8 & -6 & 0.7 & 0.4 & 2 & 139 \\
\hline & $x c$ & 38.840 & -31.8 & -7.7 & 0.8 & 0.4 & 2 & 138 \\
\hline \multirow{2}{*}{ A4 48-50 } & $m w$ & 38.913 & -31.8 & -5.9 & 0.8 & 0.4 & 2 & 129 \\
\hline & $x c$ & 38.638 & -31.8 & -12.7 & 0.8 & 0.4 & 2 & 117 \\
\hline \multirow{2}{*}{$\begin{array}{c}\text { A8 } \\
110-111\end{array}$} & $m w$ & 39.446 & -31.8 & 7.3 & 0.8 & 0.4 & 2 & 111 \\
\hline & $x c$ & 39.200 & -31.8 & 1.2 & 0.7 & 0.4 & 2 & 110 \\
\hline \multirow{2}{*}{$\begin{array}{c}\text { A14 } \\
26-30\end{array}$} & $m w$ & 39.628 & -31.8 & 11.8 & 0.7 & 0.5 & 2 & 125 \\
\hline & $x c$ & 39.240 & -31.8 & 2.2 & 0.7 & 0.4 & 2 & 122 \\
\hline
\end{tabular}

\subsection{B Isotopes and Origin of Fluids in the Gulf of Cádiz}

The affinity of the light isotope ${ }^{10} \mathrm{~B}$ for tetrahedral coordination and the heavy isotope ${ }^{11} \mathrm{~B}$ for trigonal coordination was shown by [27]. Hence, during illitization, clay minerals will concentrate ${ }^{10} \mathrm{~B}$ in the process of crystallization under hydrothermal conditions [24]. It was shown [116] that kerogen 
in the Gulf of Mexico sedimentary basin oil source rocks have a B isotopic composition of $-4 \%$ o to $+10 \%$ o. B-isotopic values from Gulf of Cadiz mud volcano samples are similar to those previously reported by [116] (Figure 9). However, mud volcano samples show higher dispersion of $\delta^{11} \mathrm{~B}$ data ranging from $-7 \%$ o to $+11.8 \%$ o for the bulk ( $\mathrm{mw}$ ) samples and from $-12.7 \%$ o to $+5.3 \%$ o for the cation exchanged (xc) clay samples (Table 5), perhaps reflecting mineralogical variations arising from mixed fluid sources, as expected in the processes of expulsion of fluids in a mud volcano. Table 5 shows that there are small differences in isotopic compositions between mannitol and cation exchanged samples indicating that the interlayer $\mathrm{B}$ is isotopically heavier than the tetrahedral-B.
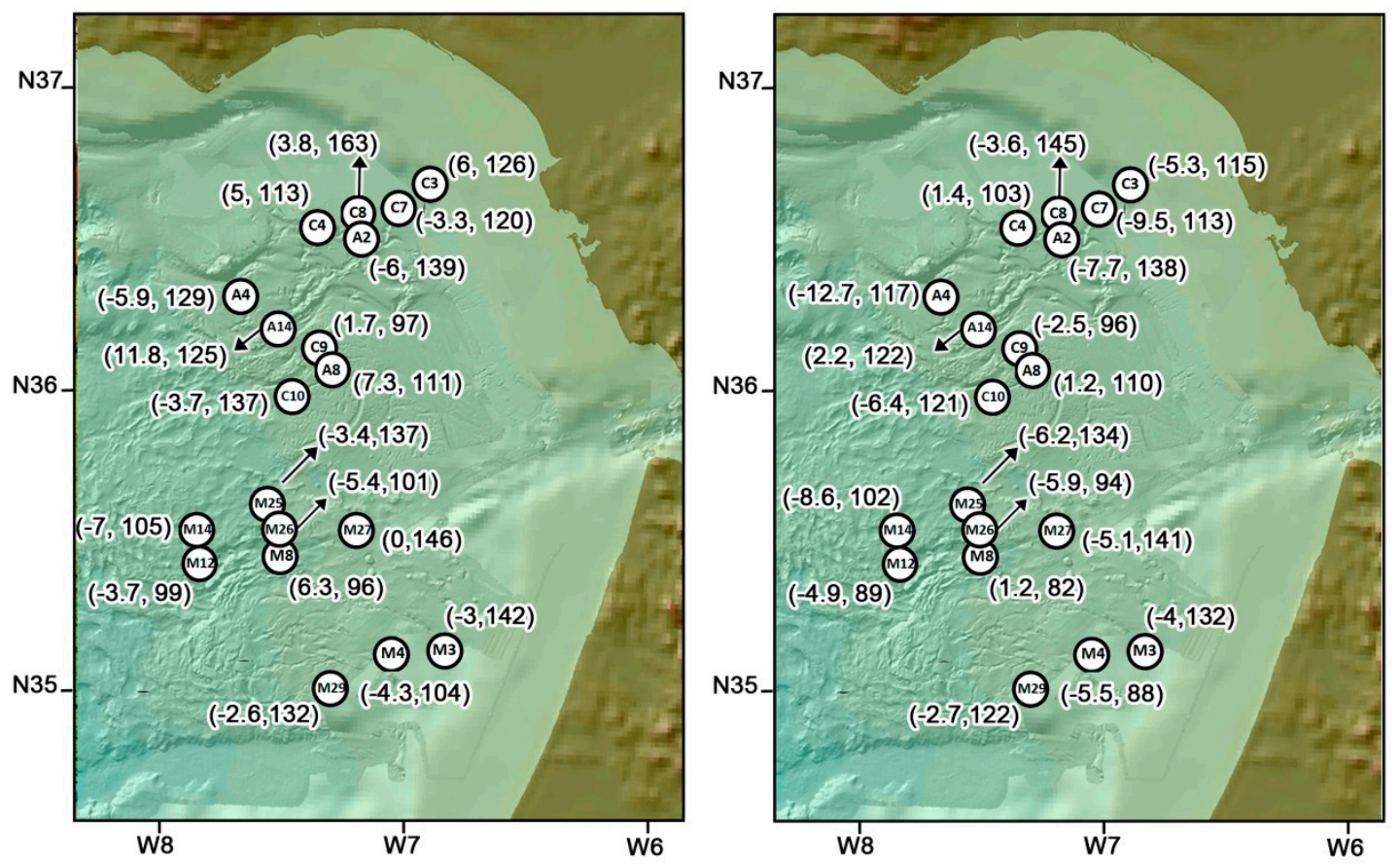

Figure 9. Gulf of Cádiz bathymetric map modified from [60] showing mud volcanoes locations with $B$ isotopes and abundances in each sample: (Left) Mannitol washed samples; and (Right) $\mathrm{NH}_{4} \mathrm{Cl}$ exchanged samples. Values in brackets are $\delta^{11} \mathrm{~B}(\% \mathrm{o}), \mathrm{B}$ content $(\mathrm{ppm})$.

Figure 10 represents B concentration and B isotope composition of MV from different locations. It can be seen that the pore fluids from MV clay minerals are ${ }^{11} \mathrm{~B}$-enriched compared to the clay minerals. While this may in part reflect the mineral-water fractionation of $B$, it also reflects the mixing of basinal water with seawater $(+39.5 \%$ o). Using the B-isotope fractionation equation for $\mathrm{pH}$ $<7$ [33], the fractionation between illite and water at $150{ }^{\circ} \mathrm{C}$ (methane generation temperature) is $-1.2 \%$. Therefore, an illite precipitated with $\delta^{11} \mathrm{~B}-12.7 \%$ o (Table 5, Sample A4 48-50 (xc)) would be in equilibrium with $+8.4 \%$ o water. This isotopically light $\delta^{11} \mathrm{~B}$ water composition, compared to seawater, is consistent with ${ }^{10} \mathrm{~B}$ enrichment from organic sources. Furthermore, Gulf of Cádiz MV samples show $\delta^{11} \mathrm{~B}$ compositions near values associated with source rock kerogen samples in other hydrocarbon-rich sedimentary basins (e.g., [99]). The higher $\delta 11 B$ values measured in some samples (up to $+5.3 \%$ ) may represent more mixing with seawater or samples less influenced by hydrocarbon-related waters. Seawater contains only about 5 ppm B, thus the high B content of the mud volcanoes requires a high fluid:rock ratio, as expected for MVs. Furthermore, where the water $\mathrm{pH}$ was higher than $\sim 8, \mathrm{~B}(\mathrm{OH})_{4}{ }^{-}$ dominates the fluid, and, because ${ }^{10} \mathrm{~B}$ prefers tetrahedral coordination, there is little fractionation between $\mathrm{B}(\mathrm{OH})_{4}{ }^{-}$dominated fluid and illite [28]. 


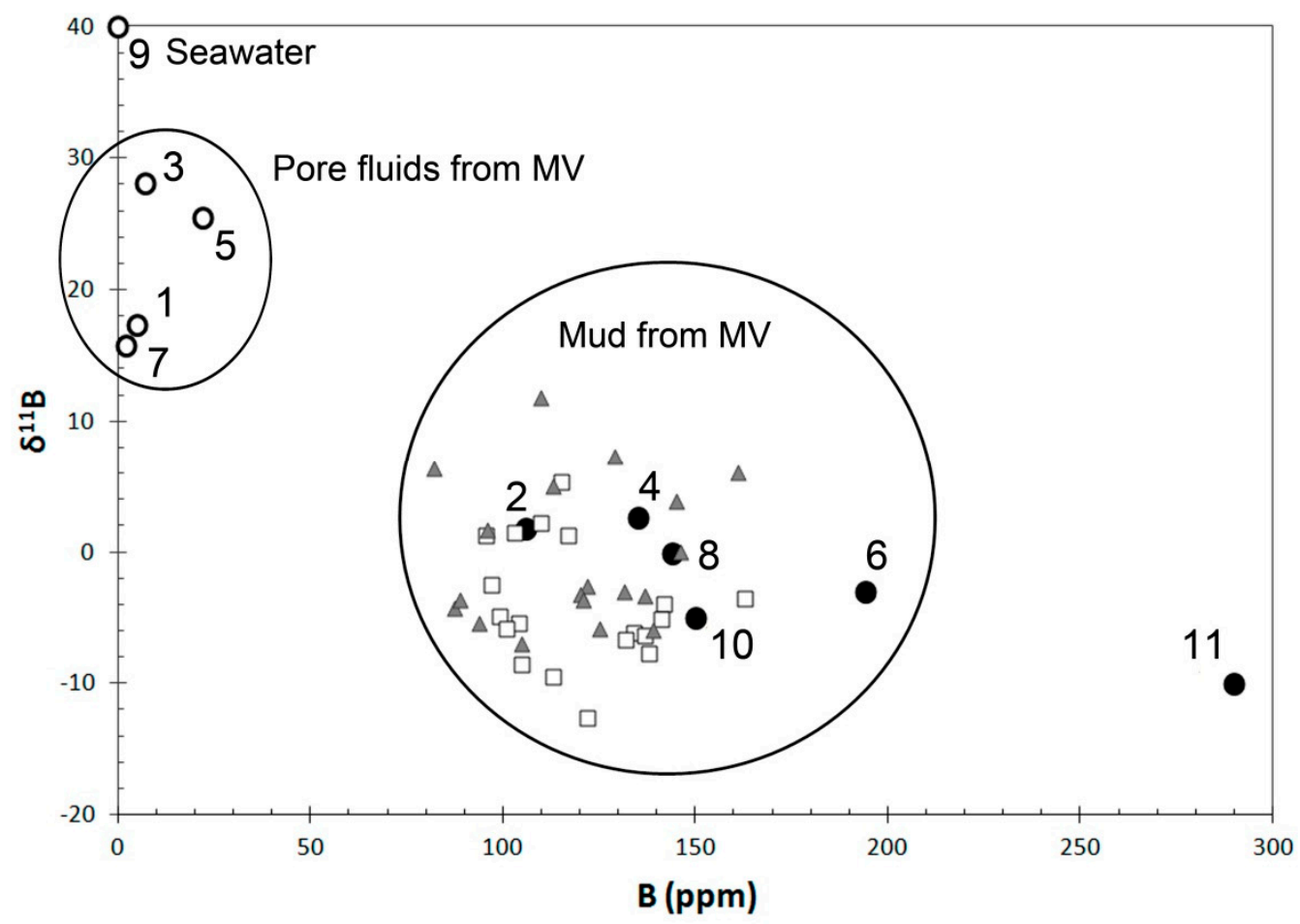

Figure 10. Summary of data of B-isotope trends and fluid/rock interactions in sedimentary basins: white squares, fixed B in xc; gray triangles, total B mw samples; 1, 2, Barbados pore fluids and mud respectively [117]; 3, 4, Makran pore fluids and mud [118]; 5, 6, Mediterranean pore fluids and mud [119]; 7, 8, Malaysia pore fluids and mud [120]; and 9, 10, 11, Seawater, source rock kerogen and muscovite pods from Gulf of Mexico, respectively [24].

These data are consistent with previous results shown by [43,45], based on $\mathrm{Li}$ and $\mathrm{Sr}$ isotope data from interstitial water, suggesting that the fluid geochemistry in MVs from the Gulf of Cádiz is influenced by overpressuring caused by clay dehydration at several kilometers depth. Temperatures approached $150{ }^{\circ} \mathrm{C}$ where thermogenic methane is produced and illitization ends. These clay and marl units underneath mud volcanoes in the Gulf of Cádiz, are Mesozoic and Tertiary in age (mainly Tortonian-Messinian) and have been considered as the oil source rock in the area [44]. A complex scenario of hydrocarbon fluid generation at depth and migration to the upper units, dehydration of clays and mixing with methane-rich fluids, and a later mixing with shallow gas was proposed by [121] to explain the distinct composition of fluids of this area. The detailed clay mineral characterization together with the B-isotopic composition is used in this study to provide additional information on the fluid geochemistry obtained in this area by the authors of $[43-46,121,122]$. These new data allow us to corroborate that illitization is an important process in the generation of fluids in MVs and can be one of the driving forces of mud volcanism in the area. Boron geochemistry is also relevant in elucidating both mineral processes and fluid origins, as previously proposed by the authors of $[25,43,102]$. This also is in agreement with other works that show the importance of the relationship of clays and petroleum in oil formation, migration, accumulation and storage [122,123].

\section{Conclusions}

Mud volcanoes in the marine environment usually involve a mixture of clays dragged up by fluids from underlying units of various depths. The detailed characterization of the clays, as well as B isotopic compositions contributes to our understanding of the geological model of the area. Those data show that mixed-layer illite-smectite phases and other clay minerals present in the mud volcano samples were derived from depths where temperatures were great enough to generate B from organic source rock. The illitization process occurs at temperatures close to oil generation [37]. During the illitization 
process, $\mathrm{B}$ released from kerogen, enriched in ${ }^{10} \mathrm{~B}$, was incorporated into the tetrahedral layer of diagenetic illite. The Gulf of Cadiz MVs are dominated by minerals with high B-content and low $\delta^{11} \mathrm{~B}$, suggesting that they formed at depth, in equilibrium with hydrocarbon-related fluids at temperatures hot enough to have generated methane that is associated with these MVs. This interpretation is supported by theoretical atomistic calculations demonstrating the preferred incorporation of ${ }^{10} \mathrm{~B}$ in the tetrahedral sheet rather than in the interlayer space of the I-S. From an oil industry point of view, this contribution is very important, as it helps to prospect for hydrocarbon reservoirs, since $\delta^{11} \mathrm{~B}$ gives information on the organic matter maturation state of the oilfield.

Author Contributions: All authors contributed to writing, reviewing and editing the final document. Conceptualization, R.M.-V. and M.P.M.; Software and computational analysis, C.I.S.-D. and R.M.-V.; XR-diffraction and TEM data and interpretation, F.N., R.M.-V., X.A.R. and M.P.M.; B analysis, L.B.W. and R.M.-V.; writing original draft preparation, R.M.-V.; and funding acquisition and supervision of the project, M.P.M. All authors have read and agreed to the published version of the manuscript.

Funding: This research was funded RNM-3581 CADHYS project and a doctoral scholarship of the Junta de Andalucía (Spain) to Rubén Martos.

Acknowledgments: Samples were obtained in the framework of TASYO (MAR-98-0209), MOUNDFORCE-EUROCORE-EUROMARGINS 01-LEC-EMA06F and INDEMARES-LIFE projects, on board of RVs Hespérides and Cornide de Saavedra. The authors thank M. Mar Abad of the Centro de Instrumentación Científica (CIC) of Granada, Andalusian project RNM-1897 and PAIDI-groups RNM-328 and RNM-363 of the Andalusia Government for the financial support, as well as the Supercomputational Center of the Granada University (UGRGRID), the Centro Técnico de Informática of CSIC and the Spanish institute of Oceanography for providing samples of mud volcanoes. We acknowledge the Arizona State University National SIMS Facility supported by the US National Science Foundation grant (EAR-0948878).

Conflicts of Interest: The authors declare no conflict of interest.

\section{References}

1. Milkov, A.V. Worldwide Distribution of Submarine Mud Volcanoes and Associated Gas Hydrates. Mar. Geol. 2000, 167, 29-42. [CrossRef]

2. Kopf, A.J. Significance of Mud Volcanism. Rev. Geophys. 2002, 40, 1005. [CrossRef]

3. Etiope, G.; Feyzullayev, A.; Baciu, C.L. Terrestrial Methane Seeps and Mud Volcanoes: A Global Perspective of Gas Origin. Mar. Pet. Geol. 2009, 26, 333-344. [CrossRef]

4. Mazzini, A.; Etiope, G. Mud Volcanism: An Updated Review. Earth Sci. Rev. 2017, 168, 81-112. [CrossRef]

5. Bonini, M. Mud Volcanoes: Indicators of Stress Orientation and Tectonic Controls. Earth Sci. Rev. 2012, 115, 121-152. [CrossRef]

6. Dimitrov, L.I. Mud Volcanoes-the Most Important Pathway for Degassing Deeply Buried Sediments. Earth Sci. Rev. 2002, 59, 49-76. [CrossRef]

7. Bonini, M.; Tassi, F.; Feyzullayev, A.-A.; Aliyev, C.S.; Capecchiacci, F.; Minissale, A. Deep Gases Discharged from Mud Volcanoes of Azerbaijan: New Geochemical Evidence. Mar. Pet. Geol. 2013, 43, 450-463. [CrossRef]

8. Mazzini, A. Mud Volcanism: Processes and Implications. Mar. Pet. Geol. 2009, 26, 1677-1680. [CrossRef]

9. Sokol, E.; Kokh, S.; Kozmenko, O.; Novikova, S.; Khvorov, P.; Nigmatulina, E.; Belogub, E.; Kirillov, M. Mineralogy and Geochemistry of Mud Volcanic Ejecta: A New Look at Old Issues (A Case Study from the Bulganak Field, Northern Black Sea). Minerals 2018, 8, 344. [CrossRef]

10. Loher, M.; Pape, T.; Marcon, Y.; Römer, M.; Wintersteller, P.; Praeg, D.; Torres, M.; Sahling, H.; Bohrmann, G. Mud Extrusion and Ring-Fault Gas Seepage-Upward Branching Fluid Discharge at a Deep-Sea Mud Volcano. Sci. Rep. 2018, 8, 6275. [CrossRef]

11. Etiope, G.; Milkov, A.V. A New Estimate of Global Methane Flux from Onshore and Shallow Submarine Mud Volcanoes to the Atmosphere. Environ. Geol. 2004, 46, 997-1002. [CrossRef]

12. Etiope, G. Natural Gas. Seepage: The Earth's Hydrocarbon Degassing; Springer-Verlag: Berlin, Germany, 2015. [CrossRef]

13. López-Rodríguez, C.; De Lange, G.J.; Comas, M.; Martínez-Ruiz, F.; Nieto, F.; Sapart, C.J.; Mogollón, J.M. Recent, Deep-Sourced Methane/Mud Discharge at the Most Active Mud Volcano in the Western Mediterranean. Mar. Geol. 2019, 408. [CrossRef] 
14. Hower, J.; Eslinger, E.V.; Hower, M.E.; Perry, E.A. Mechanism of Burial Metamorphism of Argillaceous Sediment: 1. Mineralogical and Chemical Evidence. Bull. Geol. Soc. Am. 1976, 87, 725-737. [CrossRef]

15. Abid, I.A.; Hesse, R.; Harper, J.D. Variations in Mixed-Layer Illite/Smectite Diagenesis in the Rift and Post-Rift Sediments of the Jeanne d'Arc Basin, Grand Banks Offshore Newfoundland, Canada. Can. J. Earth Sci. 2004, 41, 401-429. [CrossRef]

16. Arostegui, J.; Sangüesa, F.J.; Nieto, F.; Uriarte, J.A. Thermal Models and Clay Diagenesis in the Tertiary-Cretaceous Sediments of the Alava Block (Basque-Cantabrian Basin, Spain). Clay Miner. 2006, 41, 791-809. [CrossRef]

17. Velde, B.; Vasseur, G. Estimation of the Diagenetic Smectite to Illite Transformation in Time-Temperature Space. Am. Miner. 1992, 77, 967-976.

18. Altaner, S.P.; Ylagan, R.F. Comparison of Structural Models of Mixed-Layer Illite/Smectite and Reaction Mechanisms of Smectite Illitization. Clays Clay Miner. 1997, 45, 517-533. [CrossRef]

19. Merriman, R.J.; Peacor, D.R. Very Low-Grade Metapelites: Mineralogy, Microfabrics and Measuring Reaction Progress. In Low-Grade Metamorphism; Martin, F., Doug, R., Eds.; Blackwell Publishing Ltd.: Oxford, UK, 1999; pp. 10-60. [CrossRef]

20. Goldschmidt, V.M.; Peters, C. The Geochemistry of Boron. In The Geochemistry of Boron; Walker, C.T., Ed.; Dowden, Hutchinson and Ross: Stroudsburg, PA, USA, 1932.

21. Harder, H. Boron Content of Sediments as a Tool in Facies Analysis. Sediment. Geol. 1970, 4, 153-175. [CrossRef]

22. Spivack, A.J.; Palmer, M.R.; Edmond, J.M. The Sedimentary Cycle of the Boron Isotopes. Geochim. Cosmochim. Acta 1987, 51, 1939-1949. [CrossRef]

23. Govett, G.J.S. Introduction to Exploration Geochemistry: AA Levinson. J. Geol. 1976, 84, 503-504. [CrossRef]

24. Williams, L.B.; Hervig, R.L.; Holloway, J.R.; Hutcheon, I. Boron Isotope Geochemistry during Diagenesis. Part I. Experimental Determination of Fractionation during Illitization of Smectite. Geochim. Cosmochim. Acta 2001, 65, 1769-1782. [CrossRef]

25. Williams, L.B.; Hervig, R.L. Exploring Intra-Crystalline B-Isotope Variations in Mixed-Layer Illite-Smectite. Am. Mineral. 2002, 87, 1564-1570. [CrossRef]

26. Palmer, M.R.; Spivack, A.J.; Edmond, J.M. Temperature and PH Controls over Isotopic Fractionation during Adsorption of Boron on Marine Clay. Geochim. Cosmochim. Acta 1987, 51, 2319-2323. [CrossRef]

27. Palmer, M.R.; Swihart, G.H. Boron Isotope Geochemistry: An Overview. Rev. Mineral. 1996, 33, 708-744.

28. Hervig, R.L.; Moore, G.M.; Williams, L.B.; Peacock, S.M.; Holloway, J.R.; Roggensack, K. Isotopic and Elemental Partitioning of Boron between Hydrous Fluid and Silicate Melt. Am. Mineral. 2002, 87, 769-774. [CrossRef]

29. Pennisi, M.; Bianchini, G.; Kloppmann, W.; Muti, A. Chemical and Isotopic (B, Sr) Composition of Alluvial Sediments as Archive of a Past Hydrothermal Outflow. Chem. Geol. 2009, 266, 123-134. [CrossRef]

30. Schwarcz, H.P.; Agyei, E.K.; McMullen, C.C. Boron Isotopic Fractionation during Clay Adsorption from Sea-Water. Earth Planet. Sci. Lett. 1969, 6, 1-5. [CrossRef]

31. Keren, R.; Mezuman, U. Boron Adsorption by Clay Minerals Using a Phenomenological Equation. Clays Clay Miner. 1981, 29, 198-204. [CrossRef]

32. Środon, J. Evolution of Boron and Nitrogen Content During Illitization of Bentonites. Clays Clay Miner. 2010, 58, 743-756. [CrossRef]

33. Williams, L.B.; Clauer, N.; Hervig, R.L. Quantitative Mineralogy and Microanalysis of Sediments and Sedimentary Rockstle. In Quantitative Mineralogy and Microanalysis of Sediments and Sedimentary Rocks; Mineralogical Association of Canada Short Course: Québec, QC, Canada, 2012; pp. 55-73.

34. Williams, L.B.; Środoń, J.; Huff, W.D.; Clauer, N.; Hervig, R.L. Light Element Distributions (N, B, Li) in Baltic Basin Bentonites Record Organic Sources. Geochim. Cosmochim. Acta 2013, 120, 582-599. [CrossRef]

35. Bobos, I.; Williams, L.B. Boron, Lithium and Nitrogen Isotope Geochemistry of NH4-Illite Clays in the Fossil Hydrothermal System of Harghita Bãi, East Carpathians, Romania. Chem. Geol. 2017, 473, 22-39. [CrossRef]

36. Köster, M.H.; Williams, L.B.; Kudejova, P.; Gilg, H.A. The Boron Isotope Geochemistry of Smectites from Sodium, Magnesium and Calcium Bentonite Deposits. Chem. Geol. 2019, 510, 166-187. [CrossRef]

37. Eberl, D.D. Three Zones for Illite Formation during Burial Diagenesis and Metamorphism. Clays Clay Miner. 1993, 41, 26-37. [CrossRef] 
38. Molina-Montes, E.; Donadio, D.; Hernández-Laguna, A.; Sainz-Díaz, C.I. DFT Research on the Dehydroxylation Reaction of Pyrophyllite 2. Characterization of Reactants, Intermediates, and Transition States along the Reaction Path. J. Phys. Chem. A 2008, 112, 6373-6383. [CrossRef] [PubMed]

39. Sainz-Diaz, C.I.; Escamilla-Roa, E.; Hernández-Laguna, A. Quantum Mechanical Calculations of Trans-Vacant and Cis-Vacant Polymorphism in Dioctahedral 2:1 Phyllosilicates. Am. Mineral. 2005, 90, 1827-1834. [CrossRef]

40. Palin, E.J.; Dove, M.T.; Hernández-Laguna, A.; Sainz-Díaz, C.I. A Computational Investigation of the $\mathrm{Al} / \mathrm{Fe} / \mathrm{Mg}$ Order-Disorder Behavior in the Dioctahedral Sheet of Phyllosilicates. Am. Mineral. 2004, 89, 164-175. [CrossRef]

41. Ay, A.N.; Zumreoglu-Karan, B.; Kalinichev, A.G.; Rives, V.; Trujillano, R.; Temel, A. Layered Double Hydroxide-Borate Composites Supported on Magnetic Nanoparticles: Preparation, Characterization and Molecular Dynamics Simulations. J. Porous Mater. 2020, 27, 735-743. [CrossRef]

42. Hensen, C.; Nuzzo, M.; Hornibrook, E.; Pinheiro, L.M.; Bock, B.; Magalhães, V.H.; Brückmann, W. Sources of Mud Volcano Fluids in the Gulf of Cadiz-Indications for Hydrothermal Imprint. Geochim. Cosmochim. Acta 2007, 71, 1232-1248. [CrossRef]

43. Nuzzo, M.; Hornibrook, E.R.C.; Gill, F.; Hensen, C.; Pancost, R.D.; Haeckel, M.; Reitz, A.; Scholz, F.; Magalhães, V.H.; Brückmann, W.; et al. Origin of Light Volatile Hydrocarbon Gases in Mud Volcano Fluids, Gulf of Cadiz-Evidence for Multiple Sources and Transport Mechanisms in Active Sedimentary Wedges. Chem. Geol. 2009, 266, 350-363. [CrossRef]

44. Scholz, F.; Hensen, C.; Reitz, A.; Romer, R.L.; Liebetrau, V.; Meixner, A.; Weise, S.M.; Haeckel, M. Isotopic Evidence (87Sr/86Sr, $\triangle 7 \mathrm{Li}$ ) for Alteration of the Oceanic Crust at Deep-Rooted Mud Volcanoes in the Gulf of Cadiz, NE Atlantic Ocean. Geochim. Cosmochim. Acta 2009, 73, 5444-5459. [CrossRef]

45. Scholz, F.; Hensen, C.; De Lange, G.J.; Haeckel, M.; Liebetrau, V.; Meixner, A.; Reitz, A.; Romer, R.L. Lithium Isotope Geochemistry of Marine Pore Waters - Insights from Cold Seep Fluids. Geochim. Cosmochim. Acta 2010, 74, 3459-3475. [CrossRef]

46. Haffert, L.; Haeckel, M.; Liebetrau, V.; Berndt, C.; Hensen, C.; Nuzzo, M.; Reitz, A.; Scholz, F.; Schönfeld, J.; Perez-Garcia, C.; et al. Fluid Evolution and Authigenic Mineral Paragenesis Related to Salt Diapirism-The Mercator Mud Volcano in the Gulf of Cadiz. Geochim. Cosmochim. Acta 2013, 106, 261-286. [CrossRef]

47. Schmidt, C.; Burwicz, E.; Hensen, C.; Wallmann, K.; Martínez-Loriente, S.; Gràcia, E. Genesis of Mud Volcano Fluids in the Gulf of Cadiz Using a Novel Basin-Scale Model Approach. Geochim. Cosmochim. Acta 2018, 243, 186-204. [CrossRef]

48. Williams, L.B.; Crawford, E.W.; Hervig, R.L. Tracing Hydrocarbons in Gas Shale Using Lithium and Boron Isotopes: Denver Basin USA, Wattenberg Gas Field. Chem. Geol. 2015, 417, 404-413. [CrossRef]

49. Teichert, Z.; Bose, M.; Williams, L.B. Lithium Isotope Compositions of U.S. Coals and Source Rocks: Potential Tracer of Hydrocarbons. Chem. Geol. 2020, 549, 119694. [CrossRef]

50. Maldonado, A.; Somoza, L.; Pallarés, L. The Betic Orogen and the Iberian-African Boundary in the Gulf of Cadiz: Geological Evolution (Central North Atlantic). Mar. Geol. 1999, 155, 9-43. [CrossRef]

51. Medialdea, T.; Vegas, R.; Somoza, L.; Vázquez, J.T.; Maldonado, A.; Díaz-Del-Río, V.; Maestro, A.; Córdoba, D.; Fernández-Puga, M.C. Structure and Evolution of the "Olistostrome" Complex of the Gibraltar Arc in the Gulf of Cádiz (Eastern Central Atlantic): Evidence from Two Long Seismic Cross-Sections. Mar. Geol. 2004, 209, 173-198. [CrossRef]

52. Casas, D.; Ercilla, G.; Baraza, J. Acoustic Evidences of Gas in the Continental Slope Sediments of the Gulf of Cadiz (E Atlantic). Geo Mar. Lett. 2003, 23, 300-310. [CrossRef]

53. Somoza, L.; Díaz del Río, V.; León, R.; Ivanov, M.; Fernández-Puga, M.C.; Gardner, J.M.; Hernández-Molina, F.J.; Pinheiro, L.M.; Rodero, J.; Lobato, A.; et al. Seabed Morphology and Hydrocarbon Seepage in the Gulf of Cádiz Mud Volcano Area: Acoustic Imagery, Multibeam and Ultra-High Resolution Seismic Data. Mar. Geol. 2003, 195, 153-176. [CrossRef]

54. Fernández-Puga, M.C.; Vázquez, J.T.; Somoza, L.; Díaz del Rio, V.; Medialdea, T.; Mata, M.P.; León, R. Gas-Related Morphologies and Diapirism in the Gulf of Cádiz. Geo Mar. Lett. 2007, 27, 213-221. [CrossRef]

55. León, R.; Somoza, L.; Medialdea, T.; Vázquez, J.T.; González, F.J.; López-González, N.; Casas, D.; del Pilar Mata, M.; del Fernández-Puga, M.C.; Giménez-Moreno, C.J.; et al. New Discoveries of Mud Volcanoes on the Moroccan Atlantic Continental Margin (Gulf of Cádiz): Morpho-Structural Characterization. Geo Mar. Lett. 2012, 32, 473-488. [CrossRef] 
56. León, R.; Somoza, L.; Medialdea, T.; González, F.J.; Díaz-del-Río, V.; Fernández-Puga, M.C.; Maestro, A.; Mata, M.P. Sea-Floor Features Related to Hydrocarbon Seeps in Deepwater Carbonate-Mud Mounds of the Gulf of Cádiz: From Mud Flows to Carbonate Precipitates. Geo Mar. Lett. 2007, 27, 237-247. [CrossRef]

57. Palomino, D.; López-González, N.; Vázquez, J.-T.; Fernández-Salas, L.-M.; Rueda, J.-L.; Sánchez-Leal, R.; Díaz-del-Río, V. Multidisciplinary Study of Mud Volcanoes and Diapirs and Their Relationship to Seepages and Bottom Currents in the Gulf of Cádiz Continental Slope (Northeastern Sector). Mar. Geol. 2016, 378, 196-212. [CrossRef]

58. Toyos, M.H.; Medialdea, T.; León, R.; Somoza, L.; González, F.J.; Meléndez, N. Evidence of Episodic Long-Lived Eruptions in the Yuma, Ginsburg, Jesús Baraza and Tasyo Mud Volcanoes, Gulf of Cádiz. Geo Mar. Lett. 2016, 36, 197-214. [CrossRef]

59. Carvalho, L.; Monteiro, R.; Figueira, P.; Mieiro, C.; Almeida, J.; Pereira, E.; Magalhães, V.; Pinheiro, L.; Vale, C. Vertical Distribution of Major, Minor and Trace Elements in Sediments from Mud Volcanoes of the Gulf of Cadiz: Evidence of Cd, As and Ba Fronts in Upper Layers. Deep Sea Res. Part. I Oceanogr. Res. Pap. 2018, 131, 133-143. [CrossRef]

60. Díaz-del-Río, V.; Somoza, L.; Martínez-Frias, J.; Mata, M.P.; Delgado, A.; Hernandez-Molina, F.J.; Lunar, R.; Martín-Rubí, J.A.; Maestro, A.; Fernández-Puga, M.C.; et al. Vast Fields of Hydrocarbon-Derived Carbonate Chimneys Related to the Accretionary Wedge/Olistostrome of the Gulf of Cádiz. Mar. Geol. 2003, 195. [CrossRef]

61. Martín-Puertas, C.; Mata, M.P.; Fernández-Puga, M.C.; Díaz del Río, V.; Vázquez, J.T.; Somoza, L. A Comparative Mineralogical Study of Gas-Related Sediments of the Gulf of Cádiz. Geo Mar. Lett. 2007, 27. [CrossRef]

62. Jackson, M.L. Soil Chemical Analysis-Advanced Course. In Soil Chemical Analysis: Advanced Course, 2nd ed.; M.L.Jackson: Madison, WI, USA, 1969.

63. Huff, W.D. X-Ray Diffraction and the Identification and Analysis of Clay Minerals. Clays Clay Miner. 1990, 38, 448. [CrossRef]

64. Moore, D.M.; Reynolds, R.C.J. X-Ray Diffraction and the Identification and Analysis of Clay Minerals, 2nd ed.; Oxford University Press: Oxford, UK, 1997.

65. Arostegui, J.; Arroyo, X.; Nieto, F.; Bauluz, B. Evolution of Clays in Cretaceous Marly Series (Alava Block, Basque Cantabrian Basin, Spain): Diagenesis and Detrital Input Control. Minerals 2019, 9, 40. [CrossRef]

66. Hervig, R.L. Boron Mineralogy, Petrology and Geochemistry. In Reviews in Mineralogy; American Mineralogist, Ed.; Mineralogical Society of America: Chantilly, VA, USA, 1996; Volume 33, pp. 789-800.

67. Chaussidon, M.; Robert, F.; Mangin, D.; Hanon, P.; Rose, E.F. Analytical Procedures for the Measurement of Boron Isotope Compositions by Ion Microprobe in Meteorites and Mantle Rocks. Geostand. Geoanal. Res. 1997, 21, 7-17. [CrossRef]

68. You, C.F.; Spivack, A.J.; Gieskes, J.M.; Martin, J.B.; Davisson, M.L. Boron Contents and Isotopic Compositions in Pore Waters: A New Approach to Determine Temperature Induced Artifacts-Geochemical Implications. Mar. Geol. 1996, 129, 351-361. [CrossRef]

69. Hingston, F. Reactions between Boron and Clays. Soil Res. 1964, 2, 83-95. [CrossRef]

70. Zhang, L.; Chan, L.-H.; Gieskes, J.M. Lithium Isotope Geochemistry of Pore Waters from Ocean Drilling Program Sites 918 and 919, Irminger Basin. Geochim. Cosmochim. Acta 1998, 62, 2437-2450. [CrossRef]

71. Catanzaro, E. Boric Acid: Isotopic and Assay Standard Reference Materials; National Bureau of Standards Institute for Materials Research: Washington, DC, USA, 1970.

72. Frisch, M.J.; Trucks, G.W.; Schlegel, H.B.; Frisch, M.J.; Trucks, G.W.; Schlegel, H.B.; Scuseria, G.E.; Robb, M.A.; Cheeseman, J.R.; Montgomery, J.A.; et al. Gaussian 03: Revision B.05. Available online: https://gaussian.com/ g03citation/ (accessed on 1 January 2003).

73. Soler, J.M.; Artacho, E.; Gale, J.D.; Garcia, A.; Junquera, J.; Ordejon, P.; Sanchez-Portal, D. The SIESTA Method for Ab Initio Order-N Materials Simulation. J. Phys. Condens. Matter 2002, 14, 2745-2779. [CrossRef]

74. Perdew, J.P.; Ruzsinszky, A.; Csonka, G.I.; Vydrov, O.A.; Scuseria, G.E.; Constantin, L.A.; Zhou, X.; Burke, K. Restoring the Density-Gradient Expansion for Exchange in Solids and Surfaces. Phys. Rev. Lett. 2008, 100, 136406. [CrossRef]

75. Troullier, N.; Martins, J. Efficient Pseudopotentials for Plane-Wave Calculations. Phys. Rev. B Condens. Matter 1991, 43, 1993-2006. [CrossRef] 
76. Hernández-Laguna, A.; Escamilla-Roa, E.; Timón, V.; Dove, M.T.; Sainz-Díaz, C.I. DFT Study of the Cation Arrangements in the Octahedral and Tetrahedral Sheets of Dioctahedral 2:1 Phyllosilicates. Phys. Chem. Miner. 2006, 33, 655-666. [CrossRef]

77. Martos-Villa, R.; Guggenheim, S.; Mata, M.P.; Sainz-Díaz, C.I.; Nieto, F. Interaction of Methane Hydrate Complexes with Smectites: Experimental Results Compared to Molecular Models. Am. Mineral. 2014, 99. [CrossRef]

78. Martos-Villa, R.; Francisco-Márquez, M.; Mata, M.P.; Sainz-Díaz, C.I. Crystal Structure, Stability and Spectroscopic Properties of Methane and $\mathrm{CO}_{2}$ Hydrates. J. Mol. Graph. Model. 2013, 44. [CrossRef]

79. Martos-Villa, R.; Mata, M.P.; Sainz-Díaz, C.I. Characterization of $\mathrm{CO}_{2}$ and Mixed Methane/CO $\mathrm{CO}_{2} \mathrm{Hydrates}$ Intercalated in Smectites by Means of Atomistic Calculations. J. Mol. Graph. Model. 2014, 49. [CrossRef]

80. Ortega-Castro, J.; Hernández-Haro, N.; Hernández-Laguna, A.; Sainz-Díaz, C.I. DFT Calculation of Crystallographic Properties of Dioctahedral 2:1 Phyllosilicates. Clay Miner. 2008, 43, 351-361. [CrossRef]

81. Tossell, J.A. Theoretical Studies on Aluminate and Sodium Aluminate Species in Models for Aqueous Solution: $\mathrm{A} 1(\mathrm{OH})_{3}, \mathrm{Al}(\mathrm{OH})_{4}{ }^{-}$, and $\mathrm{NaAl}(\mathrm{OH})_{4}$. Am. Mineral. 1999, 84, 1641-1649. [CrossRef]

82. Tossell, J.A. Boric Acid, "Carbonic" Acid, and N-Containing Oxyacids in Aqueous Solution: Ab Initio Studies of Structure, PKa, NMR Shifts, and Isotopic Fractionations. Geochim. Cosmochim. Acta 2005, 69, 5647-5658. [CrossRef]

83. Lee, J.H.; Guggenheim, S. Single Crystal X-Ray Refinement of Pyrophyllite-1Tc. Am. Mineral. 1981, 66, 350-357.

84. Sainz-Diaz, C.I.; Palin, E.J.; Hernández-Laguna, A.; Dove, M.T. Octahedral Cation Ordering of Illite and Smectite. Theoretical Exchange Potential Determination and Monte Carlo Simulations. Phys. Chem. Miner. 2003, 30, 382-392. [CrossRef]

85. Ferrage, E.; Vidal, O.; Mosser-Ruck, R.; Cathelineau, M.; Cuadros, J. A Reinvestigation of Smectite Illitization in Experimental Hydrothermal Conditions: Results from X-Ray Diffraction and Transmission Electron Microscopy. Am. Mineral. 2011, 96, 207-223. [CrossRef]

86. Velde, B. Clay Minerals: A Physico-Chemical Explanation of Their Occurrence; Velde, B., Ed.; Elsevier: Amsterdam, The Netherlands, 1985. [CrossRef]

87. Arroyo Rey, X. Evolución de Las Esmectitas e Interestratificados I/S En La Serie Carbonatada Del Cretácico Superior Del Bloque Alavés. Implicaciones Sobre El Mecanismo de Illitización Durante La Diagénesis. Ph.D. Thesis, Universidad del País Vasco/Euskal Herriko Unibertsitatea, Bilbao, Spain, 2010.

88. Applegarth, L.M.S.G.A.; Pye, C.C.; Cox, J.S.; Tremaine, P.R. Raman Spectroscopic and Ab Initio Investigation of Aqueous Boric Acid, Borate, and Polyborate Speciation from 25 to $80^{\circ} \mathrm{C}$. Ind. Eng. Chem. Res. 2017, 56, 13983-13996. [CrossRef]

89. James Evans, R.; Rustad, J.R.; Casey, W.H. Calculating Geochemical Reaction Pathways-Exploration of the Inner-Sphere Water Exchange Mechanism in $\mathrm{Al}\left(\mathrm{H}_{2} \mathrm{O}\right) 63+(\mathrm{Aq})+\mathrm{NH}_{2} \mathrm{O}$ with $\mathrm{Ab}$ Initio Calculations and Molecular Dynamics. J. Phys. Chem. A 2008, 112, 4125-4140. [CrossRef]

90. Bylaska, E.J.; Valiev, M.; Rustad, J.R.; Weare, J.H. Structure and Dynamics of the Hydration Shells of the $\mathrm{Al}^{3+}$ Ion. J. Chem. Phys. 2007, 126, 104505. [CrossRef]

91. Gualtieri, A.F. Accuracy of XRPD QPA Using the Combined Rietveld-RIR Method. J. Appl. Crystallogr. 2000, 33, 267-278. [CrossRef]

92. Rustad, J.R.; Bylaska, E.J.; Jackson, V.E.; Dixon, D.A. Calculation of Boron-Isotope Fractionation between $\mathrm{B}(\mathrm{OH})_{3}(\mathrm{Aq})$ and $\mathrm{B}(\mathrm{OH})_{4}-(\mathrm{Aq})$. Geochim. Cosmochim. Acta 2010, 74, 2843-2850. [CrossRef]

93. Burst, J.F. Diagenesis of Gulf Coast Clayey Sediments and Its Possible Relation to Petroleum Migration. AAPG Bull. 1969, 58, 553-554.

94. Pollastro, R.M. Considerations and Applications of the Illite/Smectite Geothermometer in Hydrocarbon-Bearing Rocks of Miocene to Mississippian Age. Clays Clay Miner. 1993, 41, 119-133. [CrossRef]

95. Hillier, S. Illite/Smectite Diagenesis in Devonian Lacustrine Mudrocks from Northern Scotland and Its Relationship to Organic Maturity Indicators. Clay Miner. 1989, 24, 181-196. [CrossRef]

96. Hillier, S.; Mátyás, J.; Matter, A.; Vasseur, G. Illite/Smectite Diagenesis and Its Variable Correlation with Vitrinite Reflectance in the Pannonian Basin. Clays Clay Miner. 1995, 43, 174-183. [CrossRef] 
97. Bauluz, B.; Peacor, D.R.; Gonzalez Lopez, J.M. Transmission Electron Microscopy Study of Illitization in Pelites from the Iberian Range, Spain: Layer-by-Layer Replacement? Clays Clay Miner. 2000, 48, 374-384. [CrossRef]

98. Huggett, J.M.; Cuadros, J. Low-Temperature Illitization of Smectite in the Late Eocene and Early Oligocene of the Isle of Wight (Hampshire Basin), U.K. Am. Mineral. 2005, 90, 1192-1202. [CrossRef]

99. Clauer, N.; Williams, L.B.; Fallick, A.E. Genesis of Nanometric Illite Crystals Elucidated by Light-Element (Hydrogen, Lithium, Boron and Oxygen) Isotope Tracing, and $\mathrm{K}-\mathrm{Ar}$ and $\mathrm{Rb}-\mathrm{Sr}$ Dating. Chem. Geol. 2014, 383, 26-50. [CrossRef]

100. Perry, E.A. Diagenesis and the Validity of the Boron Paleosalinity Technique. Am. J. Sci. 1972, 272, $150-160$. [CrossRef]

101. Kopf, A.; Deyhle, A. Back to the Roots: Boron Geochemistry of Mud Volcanoes and Its Implications for Mobilization Depth and Global B Cycling. Chem. Geol. 2002, 192, 195-210. [CrossRef]

102. Sokol, E.V.; Kokh, S.N.; Kozmenko, O.A.; Lavrushin, V.Y.; Belogub, E.V.; Khvorov, P.V.; Kikvadze, O.E. Boron in an Onshore Mud Volcanic Environment: Case Study from the Kerch Peninsula, the Caucasus Continental Collision Zone. Chem. Geol. 2019, 525, 58-81. [CrossRef]

103. Środoń, J.; Paszkowski, M. Role of Clays in the Diagenetic History of Nitrogen and Boron in the Carboniferous of Donbas (Ukraine). Clay Miner. 2011, 46, 561-582. [CrossRef]

104. Lindgreen, H.; Drits, V.A.; Sakharov, B.A.; Salyn, A.L.; Wrang, P.; Dainyak, L.G. Illite-Smectite Structural Changes during Metamorphism in Black Cambrian Alum Shales from the Baltic Area. Am. Mineral. 2000, 85, 1223-1238. [CrossRef]

105. Boudou, J.P.; Schimmelmann, A.; Ader, M.; Mastalerz, M.; Sebilo, M.; Gengembre, L. Organic Nitrogen Chemistry during Low-Grade Metamorphism. Geochim. Cosmochim. Acta 2008, 72, 1199-1221. [CrossRef]

106. Ovsyannikov, D.O.; Sadekov, A.Y.; Kozlova, E.V. Rock Fragments from Mud Volcanic Deposits of the Gulf of Cadiz: An Insight into the Eocene-Pliocene Sedimentary Succession of the Basin. Mar. Geol. 2003, 195, 211-221. [CrossRef]

107. Chamley, H.; Dunoyer De Segonzac, G.; Melieres, F. Clay Mineralogy of Upper Miocene Sediments of the Mediterranean Basin. In Deep Sea Drilling Project Reports and Publication; U.S. Government Publishing Office: Washington, DC, USA, 1978; Volume XLI, pp. 389-395. [CrossRef]

108. Chamley, H. Geodynamic Control on Messinian Clay Sedimentation in the Central Mediterranean Sea. Geo Mar. Lett. 1989, 9, 179-184. [CrossRef]

109. De Visser, J.P. Clay Mineral Stratigraphy of Miocene to Recent Marine Sediments in the Central Mediterranean. Geol. Ultraiect. 1992, 75, 1-243.

110. Azzaro, E.; Bellanca, A.; Neri, R. Clay Mineral Studies of the Tripoli Formation (Lower Messinian), Sicily. Clay Miner. 1988, 23, 309-321. [CrossRef]

111. Daoudi, L.; Rocha, F.; Ouajhain, B.; Dinis, J.L.; Chafiki, D.; Callapez, P. Palaeoenvironmental Significance of Clay Minerals in Upper Cenomanian-Turonian Sediments of the Western High Atlas Basin (Morocco). Clay Miner. 2008, 43, 615-630. [CrossRef]

112. Van Den Berg, B.C.J.; Sierro, F.J.; Hilgen, F.J.; Flecker, R.; Larrasoaña, J.C.; Krijgsman, W.; Flores, J.A.; Mata, M.P.; Bellido Martín, E.; Civis, J.; et al. Astronomical Tuning for the Upper Messinian Spanish Atlantic Margin: Disentangling Basin Evolution, Climate Cyclicity and MOW. Glob. Planet. Chang. 2015. [CrossRef]

113. Pérez-Asensio, J.N.; Larrasoaña, J.C.; Samankassou, E.; Sierro, F.J.; Garcia-Castellanos, D.; Jiménez-Moreno, G.; Salazar, Á.; Maria Salvany, J.; Ledesma, S.; Mata, M.P.; et al. Magnetobiochronology of Lower Pliocene Marine Sediments from the Lower Guadalquivir Basin: Insights into the Tectonic Evolution of the Strait of Gibraltar Area. GSA Bull. 2018. [CrossRef]

114. Barnolas, A.; Larrasoaña, J.C.; Pujalte, V.; Schmitz, B.; Sierro, F.J.; Mata, M.P.; van den Berg, B.C.J.; Pérez-Asensio, J.N.; Salazar, Á.; Salvany, J.M.; et al. Alpine Foreland Basins. In The Geologiy of Iberia: A Geodynamic Approach; Quesada, C., Oliveira, J., Eds.; Springer: Cham, Switzerland, 2019; pp. 7-59. [CrossRef]

115. Williams, L.; Hervig, R. Boron Isotope Composition of Coals: A Potential Tracer of Organic Contaminated Fluids. Appl. Geochem. 2004, 19, 1625-1636. [CrossRef]

116. Williams, L.B.; Hervig, R.L.; Hutcheon, I. Boron Isotope Geochemistry during Diagenesis. Part II. Applications to Organic-Rich Sediments. Geochim. Cosmochim. Acta 2001, 65, 1783-1794. [CrossRef] 
117. Henry, P.; Le Pichon, X.; Lallemant, S.; Lance, S.; Martin, J.B.; Foucher, J.-P.; Fiala-Médioni, A.; Rostek, F.; Guilhaumou, N.; Pranal, V.; et al. Fluid Flow in and around a Mud Volcano Field Seaward of the Barbados Accretionary Wedge: Results from Manon Cruise. J. Geophys. Res. Solid Earth 1996, 101, 20297-20323. [CrossRef]

118. Delisle, G.; Von Rad, U.; Andruleit, H.; Von Daniels, C.; Tabrez, A.; Inam, A. Active Mud Volcanoes On-And Offshore Eastern Makran, Pakistan. Int. J. Earth Sci. 2002, 91, 93-110. [CrossRef]

119. Kopf, A.; Robertson, A.H.F.; Clennell, M.B.; Flecker, R. Mechanisms of Mud Extrusion on the Mediterranean Ridge Accretionary Complex. Geo Mar. Lett. 1998, 18, 97-114. [CrossRef]

120. Clennell, M.B. The Mélanges of Sabah, Malaysia. Ph.D. Thesis, Royal Holloway, University of London, London, UK, 1992.

121. Nuzzo, M.; Tomonaga, Y.; Schmidt, M.; Valadares, V.; Faber, E.; Piñero, E.; Reitz, A.; Haeckel, M.; Tyroller, L.; Godinho, E.; et al. Formation and Migration of Hydrocarbons in Deeply Buried Sediments of the Gulf of Cadiz Convergent Plate Boundary-Insights from the Hydrocarbon and Helium Isotope Geochemistry of Mud Volcano Fluids. Mar. Geol. 2019, 410, 56-69. [CrossRef]

122. Pan, C.; Jiang, L.; Liu, J.; Zhang, S.; Zhu, G. The Effects of Calcite and Montmorillonite on Oil Cracking in Confined Pyrolysis Experiments. Org. Geochem. 2010, 41, 611-626. [CrossRef]

123. Lei, H.; Shi, Y.; Guan, P.; Fang, X. Catalysis of Aluminosilicate Clay Minerals to the Formation of the Transitional Zone Gas. Sci. China Ser. D Earth Sci. 1997, 40, 130-136. [CrossRef]

(C) 2020 by the authors. Licensee MDPI, Basel, Switzerland. This article is an open access article distributed under the terms and conditions of the Creative Commons Attribution (CC BY) license (http://creativecommons.org/licenses/by/4.0/). 